\title{
Modeling reproductive traits of an invasive bivalve species under contrasting climate scenarios from 1960 to 2100
}

\author{
Gourault Mélaine ${ }^{1,{ }^{\star}}$, Petton Sébastien ${ }^{1}$, Thomas Yoann ${ }^{2}$, Pecquerie Laure ${ }^{2}$, Marques Gonçalo M. ${ }^{3}$, \\ Cassou Christophe ${ }^{4}$, Fleury Elodie ${ }^{5}$, Paulet Yves-Marie ${ }^{2}$, Pouvreau Stéphane ${ }^{1}$
}

${ }^{1}$ Ifremer, Laboratoire des Sciences de l'Environnement Marin (LEMAR), 29840 Argenton-en-

Landunvez, France

${ }^{2}$ Laboratoire des Sciences de l'Environnement Marin (LEMAR), UBO, CNRS, IRD, Ifremer, Plouzané, France

${ }^{3}$ MARETEC, Instituto Superior Técnico, University of Lisbon, 1049-001 Lisboa, Portugal

${ }^{4}$ C.E.R.F.A.C.S, 31057 Toulouse Cedex 01, France

${ }^{5}$ Ifremer, Laboratoire des Sciences de l'Environnement Marin (LEMAR), 29280 Plouzané, France

* Corresponding author : Mélaine Gourault, email address : melaine.gourault@gmail.com

\begin{abstract}
:
Identifying the drivers that control the reproductive success of a population is vital to forecasting the consequences of climate change in terms of distribution shift and population dynamics. In the present study, we aimed to improve our understanding of the environmental conditions that allowed the colonization of the Pacific oyster, Crassostrea gigas, in the Bay of Brest since its introduction in the 1960s. We also aimed to evaluate the potential consequences of future climate change on its reproductive success and further expansion.
\end{abstract}

Three reproductive traits were defined to study the success of the reproduction: the spawning occurrence, synchronicity among individuals and individual fecundity. We simulated these traits by applying an individual-based modeling approach using a Dynamic Energy Budget (DEB) model. First, the model was calibrated for $C$. gigas in the Bay of Brest using a 6-year monitoring dataset (20092014). Second, we reconstructed past temperature conditions since 1960 in order to run the model backwards (hindcasting analysis) and identified the emergence of conditions that favored increasing reproductive success. Third, we explored the regional consequences of two contrasting IPCC climate scenarios (RCP2.6 and RCP8.5) on the reproductive success of this species in the bay for the 2100 horizon (forecasting analysis). In both analyses, since phytoplankton concentration variations were, at that point, unknown in the past and unpredicted in the future, we made an initial assumption that our six years of observed phytoplankton concentrations were informative enough to represent "past and future possibilities" of phytoplankton dynamics in the Bay of Brest. Therefore, temperature is the variable that we modified under each forecasting and hindcasting runs.

The hindcasting simulations showed that the spawning events increased after 1995, which agrees with the observations made on C. gigas colonization. The forecasting simulations showed that under the warmer scenario (RCP8.5), reproductive success would be enhanced through two complementary mechanisms: more regular spawning each year and potentially precocious spawning resulting in a larval 
phase synchronized with the most favorable summer period. Our results evidenced that the spawning dates and synchronicity between individuals mainly relied on phytoplankton seasonal dynamics, and not on temperature as expected. Future research focused on phytoplankton dynamics under different climate change scenarios would greatly improve our ability to anticipate the reproductive success and population dynamics of this species and other similar invertebrates.

\section{Highlights}

- The DEB model available for the Pacific oyster was applied in a new coastal environment: the bay of Brest (France). This version was successfully calibrated using a new dataset covering 6 years (from 2009 to 2014) of field monitoring. - The model successfully predicted in detail the complex reproductive processes of $C$. gigas, especially its spawning behavior. Hindcasting and forecasting simulations of the reproductive phenology of $C$. gigas were performed using IPCC scenarios.

Keywords : DEB model, IPCC scenarios, Reproductive traits, Crassostrea gigas, Bay of Brest 


\section{Introduction}

In the mid-1960s, the Pacific oyster Crassostrea gigas was introduced from Japan to several European locations for shellfish aquaculture. Since the early 2000s, a massive spread of this species has been observed (Dutertre et al., 2010), with the expansion of its biogeographic distribution along the northwestern European coasts surpassing the initial introduction area giving the species an invasive status in several coastal ecosystems (Thomas et al., 2016). Today, numerous wild oyster populations can be found along most of Europe's coastlines, from the northern Mediterranean Sea to southern Norway (Miossec et al., 2009), in some cases forming massive and remarkable biogenic reefs (especially along French Atlantic coasts). In Europe, the Bay of Brest (Brittany, western France) is currently the northernmost European site where oyster spat collection is cost-effective for oyster farmers. The most recent evaluation of $C$. gigas adult wild stocks in the bay revealed around 10000 tons of oysters in 2005 (Lejart, 2009), although they were insignificant in the 1980s. The increase of seawater temperature in many shallow embayments of the Bay of Brest since the 1990s is assumed to allow more successful oyster reproduction, with higher fecundity, more frequent spawning, faster larval development and thus higher recruitment rates (e.g. Thomas et al., 2016).

As a general rule, the reproductive cycle of bivalves involves several key steps: growth and ripening of gametes (gametogenesis and fecundity), gamete release or spawning (partial or total at the individual scale, synchronous or asynchronous between individuals and/or sub-populations), resting stage or regression period (in the case of no spawning) and then subsequent gonad redevelopment (Gosling, 2003). In temperate waters, where both temperature and food availability follow a seasonal cycle, oyster reproduction is also highly seasonal. Although gametogenesis can often continue for months, the spawning process is, in comparison, a very brief event, in the range of few days for $C$. gigas, (e.g. Bernard et al., 2016). This fleeting short duration event is a key step for reproduction and subsequent recruitment success, but perfect synchrony is not always achieved. Firstly, gamete release can be hindered by unfavorable environmental thermic or trophic triggers. In such cases, oysters do not spawn but instead, once ripeness is reached, the gametes start a degeneration process called 
resorption (see description of this process in Steele \& Mulcahy, 1999). Secondly, spawning can be partial for some individuals and asynchronous between individuals, in which case subsequent larval abundance remains low. Generally, spawning is total and synchronous, ensuring the efficient meeting of gametes between all individuals and maximizing the number of larvae and the subsequent recruitment (Gosling, 2003). In France, C. gigas gametogenesis occurs over the spring months and accelerates in June. Spawning events then occur between July and September, as soon as the seawater temperature exceeds $18-19^{\circ} \mathrm{C}$. In fact, for this species, it is commonly admitted that temperature has a dual effect. It drives the gametogenesis rate, with a cumulative effect (the "day-degrees" hypothesis, Mann, 1979) and acts as a threshold (instantaneous effect) to trigger spawning (Pouvreau et al., 2006; Castanos et al., 2009; Bernard et al., 2016). In addition, the overall condition index of oysters, especially the number of gametes produced (fecundity), depends directly on food availability (ChavezVillalba et al., 2002; Enriquez et al., 2009). Consequently, water temperature and phytoplankton concentration are assumed to be the main environmental factors that drive oyster reproductive processes in temperate waters.

The timing of life-history events, such as onset of gametogenesis, spawning and larval metamorphosis, are crucial, as they represent key steps in the population dynamics (Walther et al., 2002). The occurrence of these periodic biological events (i.e. phenology) has been investigated in several ecosystems and for many species. The majority of these studies highlighted that global climate change has profound impacts on species phenology (Parmesan et al., 2007). For example, based on a multi-decennial biological study of Macoma balthica in the Wadden Sea, Beukema et al. (2009) showed that global warming leads to a decrease in the reproductive effort of M. balthica and an earlier spawning date. Similar exercises were provided for other species: effect of salinity dynamics on spatfall abundance in Crassostrea virginica on the coasts of Louisiana (Soniat et al., 2006) and Maryland (Kimmel \& Newell, 2007) in the USA, positive correlation between phytoplankton abundance and mussel recruitment in Mytilus spp. on the Oregon coast in the USA (Menge et al., 2009) or effect of seawater temperature on the reproduction process in Pecten maximus in Ireland (Shephard et al., 2009), Crepidula fornicata in France (Valdizan et al., 2011), and Cerastoderma edule 
in Ireland (Morgan et al., 2013). However, these time series are often limited in their spatial and temporal resolutions and additional modeling tools are thus needed to properly analyze climate effects, describe multi-stressor interactions, and define realistic future scenarios. Since the beginning of the 1990s, several ecophysiological models have been developed in this way (Beiras et al., 1994; Navarro \& Thompson, 1996; Barillé et al., 1997). Recently, much interest has been focused on a mechanistic model based on the Dynamic Energy Budget (DEB) theory developed by Kooijman (2010). This generic modeling framework simulates bioenergetic fluxes within a living organism according to the variability of its environment through a set of equations and parameters. The advantage of this model is the possibility it offers to work at the individual level and to couple the life cycle with environmental forcing. This kind of model typically facilitates the study of biological traits in the entire life cycle of an organism and helps to better understand the population dynamics level, although the scaling up from the individual to the population level remains a challenging issue. Within the past ten years, several DEB models have been successfully developed for key bivalves, especially for Crassostrea gigas (e.g. Pouvreau et al., 2006; Bernard et al., 2011), Mytilus edulis (e.g. Rosland et al., 2009; Filgueira et al., 2011; Thomas et al., 2011), Pecten maximus (Lavaud et al., 2014), and Crassostrea virginica (Filgueira et al., 2014). More recently, DEB models shown that they are powerful tools to predict the impact of climate change on life traits in species (Thomas et al., 2016; Montalto et al., 2015)

In this context, the specific objective of this study was to examine how the reproductive ecology of $C$. gigas might be affected by climate-driven changes in temperature according to six food dynamics in the Bay of Brest. To achieve this, we chose a challenging approach involving hindcast and forecast simulations of Pacific oyster reproduction from 1960 to 2100. Using a rich biological and environmental dataset resulting from 6 years (2009-2014) of field monitoring in the Bay of Brest (seawater temperature and phytoplankton), and the Dynamic Energy Budget (DEB) model (Bernard et al., 2011), we first explored the current variability of the oyster reproductive pattern (fecundity, spawning dates, and spawning synchronicity). Second, we ran the model backwards in order to reconstruct historical spawning dates and fecundity since 1960 (hindcasting approach), and to reveal 
tendencies or shifts in the phenology of reproduction of this species since its introduction until the present day. Finally, we simulated the potential evolution of the reproductive patterns of $C$. gigas in the Bay of Brest over the next 100 years (forecasting approach) using results from climate models for two extreme IPCC (Intergovernmental Panel on Climate Change) regional climate projections: RCP2.6, the "drastic decrease of $\mathrm{CO}_{2}$ emissions" scenario and RCP8.5 the "business as usual" scenario.

\section{Material \& Methods}

\subsection{Study site}

The Bay of Brest (western Brittany, France) is a semi-enclosed marine system (Fig. 1). This shallow bay spans an area of nearly $180 \mathrm{~km}^{2}$, with a mean depth of $8 \mathrm{~m}$. It has a maximal tidal range of $8 \mathrm{~m}$ during spring tides. Approximately half of the total area has a depth less than $5 \mathrm{~m}$, offering many large and shallow embayments (mud to coarse gravel and maerl benthic beds) that are very favorable for bivalve life cycle. The intertidal and catchment areas of the rivers and streams flowing into the bay derive from the Elorn river (watershed of $402 \mathrm{~km}^{2}$ ) in the north, and the Aulne river (watershed of $1842 \mathrm{~km}^{2}$ ) in the south. The bay is connected to the Atlantic Ocean (Iroise Sea) by a small strait (1.8 $\mathrm{km}$ wide, $50 \mathrm{~m}$ deep). Strong tidal currents (5 knots in the strait and 2.5 knots inside the bay) allow water renewal, preventing eutrophication and stratification.

Shellfish aquaculture and marine fisheries generate important economic activities within the bay, with approximately 40 fishing boats (dredge fishing) and 13 shellfish producers (382 ha of concessions). Many filter-feeding species are exploited, including the flat native oyster (Ostrea edulis), the introduced Pacific oyster (Crassostrea gigas), the great scallop (Pecten maximus), the variegated scallop (Mimachlamys varia), the native mussel (Mytilus edulis), the warty venus (Venus verrucosa), the native and introduced clams (Rudipates decussatus and philippinarum), and the cockle

\section{(Cerastoderma edule).}

The Pacific oyster, introduced in the mid-1960s, is currently the most important exploited bivalve species, in term of resident biomass, inhabiting the bay. Approximately 500 tons are produced 
every year, but the wild population, forming massive biogenic reefs in many estuarine areas located in the eastern part of the bay, was estimated to be 10000 tons in 2005 (Lejart, 2009). Local densities within the reefs can reach more than 1000 individuals $/ \mathrm{m}^{2}$ and the total colonized surface was estimated to be 300 ha, with a mean oyster density of 84 individuals $/ \mathrm{m}^{2}$ (Lejart, 2009).

Within the Bay of Brest (Fig. 1), our monitoring station was located in the vicinity of the wild oyster reefs in Daoulas Bay at the Pointe du Chateau site $\left(48^{\circ} 20^{\prime} 03^{\prime \prime} \mathrm{N}, 04^{\circ} 19^{\prime} 14.5^{\prime \prime} \mathrm{W}\right.$ ) (see Petton et al., 2016). This monitoring station is part of a French national monitoring network on oysters (RESCO and VELYGER monitoring programs, https://wwz.ifremer.fr/velyger/Acces-auxDonnees/Rade-de-Brest), which was implemented after the high mortality events that occurred all along the French coast in 2008 (e.g. Pouvreau et al., 2016).

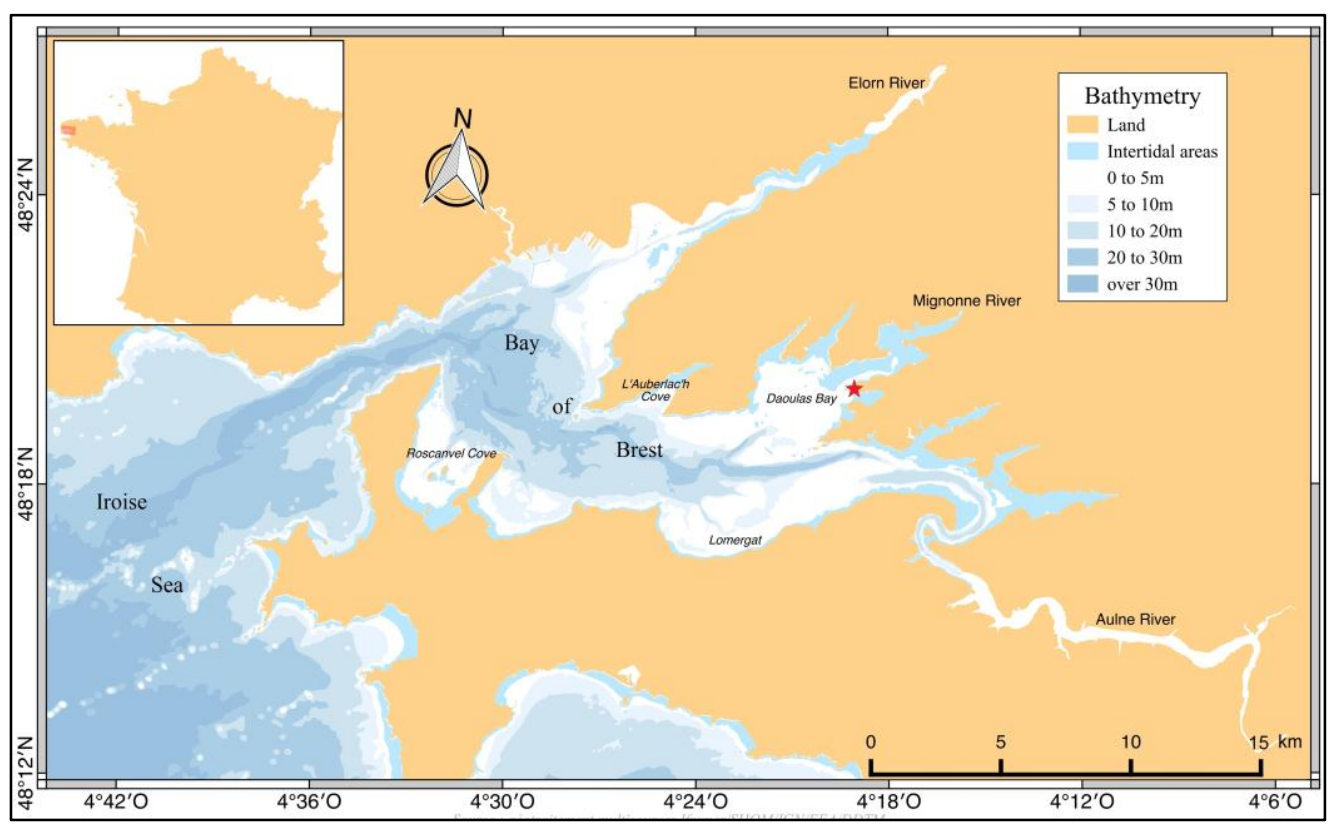

Figure 1: The Bay of Brest (western Brittany, France). The red star indicates our monitoring station ("Pointe du Chateau"), located in the vicinity of a wild oyster reef. Each year, a set of 300 adult oysters (18 months old) collected naturally as wild spat was installed and monitored at this station from March to December (see RESCO, http://wwz.ifremer.fr/observatoire conchylicole). We also monitored environmental parameters (seawater temperature, salinity, and phytoplankton) at the same location.

\subsection{Oyster-DEB model}

The oyster-DEB model was derived from the standard DEB model described by Kooijman (2010) and was first applied to C. gigas by Pouvreau et al. (2006). Model equations and parameter values (Appendix A; Tables A.1, A.2 and A.3) were mostly taken from the model of Bernard et al. 
(2011), which described the processes of energy allocation to gametogenesis and resorption in starvation conditions (Appendix A; Fig. A). This version of the model was also used and re-described by Thomas et al. (2016). To account for inter-individual variability, we followed the modeling strategy of Thomas et al. (2016), simulating 30 individuals with different initial conditions. The model was initialized with observed oyster individual shell length (L) and dry flesh mass (DFM), following the equations described in Table A3. The 30 simulated individual growth trajectories were then pooled to calculate average growth patterns and standard deviations.

Spawning is triggered when two thresholds are reached: a seawater temperature threshold $\left(\mathrm{T}_{\mathrm{S}}\right)$ set to $18.7^{\circ} \mathrm{C}$ and a gonado-somatic index threshold (GSI) of $47.2 \%$, where GSI is defined as a mass ratio between the gonadic and total DFM (Pouvreau et al., 2006). To assess fecundity, individual oocyte production was estimated from the cumulated energy allocated to the gamete buffer with the cost of production of a single oocyte set to $9.3 \times 10^{-4} \mathrm{~J}$. The gonad buffer is entirely emptied when spawning occurs (no partial spawning). Since 30 individual trajectories are simulated from real length and DFM observation, conditions leading to potential spawning asynchrony between individuals could be studied. When the conditions for spawning are not met ( $\mathrm{T}_{\mathrm{S}}$ and GSI remain below the thresholds), the energy stored in the gonad buffer is used for maintenance during low food conditions, as previously specified by Thomas et al. (2016) and Bernard et al. (2011) and described in Steele \& Mulcahy (1999).

Since the Pacific oyster is an intertidal species, an immersion time factor, $\mathrm{t}_{\mathrm{im}}$, representing the daily immersion time ratio, was applied to the ingestion function to take into account the influence of tidal emersion on oyster growth (Table A.3; Thomas et al., 2016). In this study, the value of $t_{i m}$ was estimated from high frequency measurements (every 15 minutes) during one day. During emersion, seawater temperature was used as a proxy for body temperature. Obviously, this constitutes a first approximation, since it has been demonstrated that extreme temperature variation during aerial exposure may affect oyster metabolism and survival (Seaman, 1991). However, we considered that aerial exposure in temperate environments encountered in the Bay of Brest would have limited effect, as demonstrated by Thomas et al. (2016). 


\subsection{Environmental forcing variables}

Two forcing variables are taken into account in the oyster-DEB model, namely food density and seawater temperature (Fig. 2). Both types of data were monitored from 2009 to 2014 in the eastern

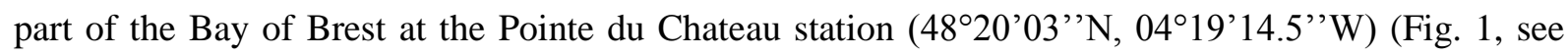
Petton et al., 2016). Daily Sea Surface Temperature (SST) data were obtained continuously by highfrequency recording with sensors (SP2T/STPS); phytoplankton concentrations were obtained through bi-weekly sampling of seawater and phytoplankton determination and counting under a microscope. As recommended by previous authors (Pouvreau et al., 2006; Bernard et al., 2011; Thomas et al., 2016), the total phytoplankton concentration (i.e. cell number per liter) was used here as a proxy for food.

The six years of environmental monitoring provided contrasting forcing conditions. The spawning temperature threshold of $18.7^{\circ} \mathrm{C}$ (which represents the threshold for spawning in the Pacific oyster) was reached in different moment according to the years: around mid-June in 2009 and 2014 (18 June in 2009 and 21 June in 2014) and around mid-July in 2012 and 2013 (23 July in 2012 and 11 July in 2013). The 6-year dataset also provided several food conditions, especially concerning the onset of the spring blooms (28 March in 2014 against 12 June in 2013) and the magnitude of the summer blooms (low in 2011 and high in 2012, 2013 and 2014).

Particulate Inorganic Matter (PIM expressed in $\mathrm{mg} / \mathrm{L}$ ) is known to play a role in oyster ingestion regulation and was previously used by Thomas et al. (2016) in a highly turbid shellfish ecosystem. We tested this third environmental parameter, but PIM concentrations are low in the Bay of Brest $(<10 \mathrm{mg} / \mathrm{L})$ and no effect was found in our model validation step. Thus, we did not consider PIM concentrations as a relevant forcing variable for the Bay of Brest location. 


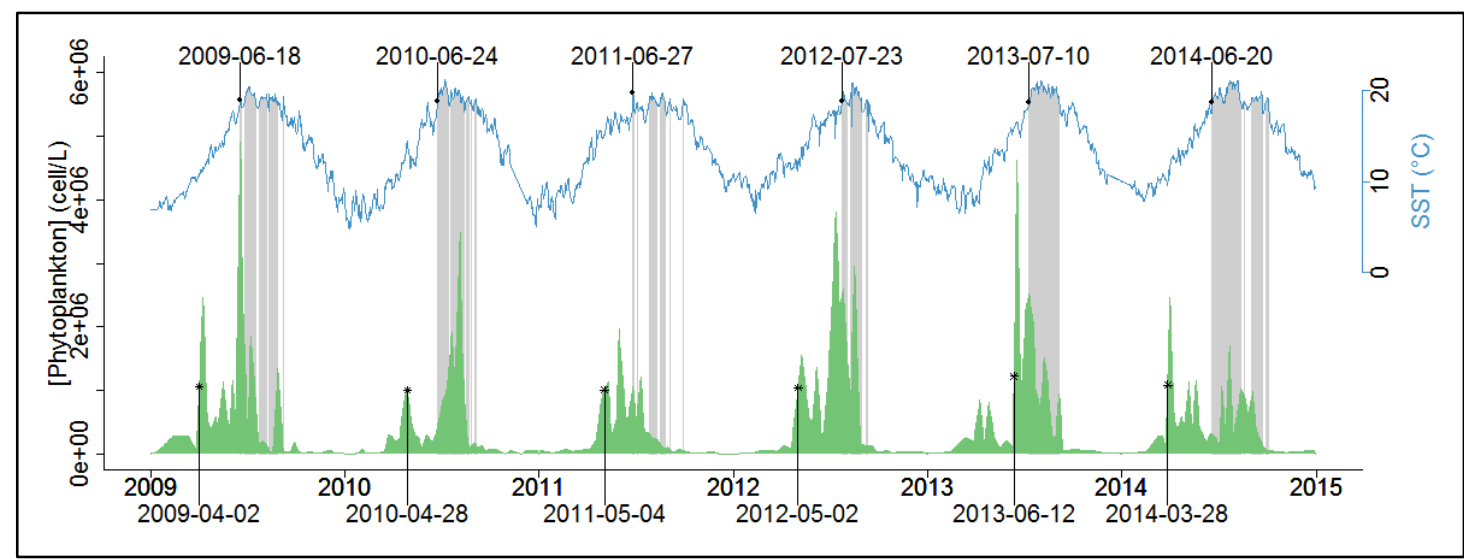

Figure 2: Environmental forcing used for the DEB model simulations, from 2009 to 2014 in the Bay of Brest: phytoplankton concentration (green) and seawater surface temperature (SST, pale blue line). Grey areas indicate temporal windows where SST is higher than $18.7^{\circ} \mathrm{C}$, the spawning threshold. The date above the graph indicates the first time SST reaches this threshold in a given year. The date below the graph indicates the first significant bloom apparition (> 1 million cells/liter).

\subsection{Oyster data for validation procedure}

Oyster growth and reproduction were monitored jointly to the environmental monitoring (Fig. 1). Each year, a set of 300 adult oysters (18 months old) was monitored from March to December. The method used is detailed on the website of the French national monitoring program on oyster growth and survival (RESCO, http://wwz.ifremer.fr/observatoire_conchylicole). Individual shell length (L) and dry flesh mass (DFM) were measured on a subset of 30 individuals, every two weeks from spring to autumn and every month in the winter for the duration of the study (from 2009 to 2014). From the regular monitoring of DFM over time, we were able to characterize four traits of the reproductive cycle: the period of gametogenesis (increase in DFM), onset of spawning (drop in DFM; within an interval of 15 days), fecundity (DFM difference before and after spawning) and autumnal regression (decrease in DFM).

\subsection{Model calibration}

As each study site has its own environmental properties (especially taxonomic phytoplankton composition and subsequent food value, but also spawning triggers potentially linked to low level regional adaptation), some parameters were calibrated for the Bay of Brest by minimizing a sum of squares deviation between the predictions and the data, namely $X_{k}$, the half saturation coefficient, which controls the oyster energy uptake, $\kappa_{\mathrm{X}}$, the assimilation efficiency, and the two spawning triggers, GSI and $\mathrm{T}_{\mathrm{s}}$. The assimilation efficiency was defined as an affine function of phytoplankton 
concentration of the type $\mathrm{ax}+\mathrm{b}$ with $\mathrm{a}=-1.8 \times 10^{-7}$ and $\mathrm{b}=0.80$. The $\mathrm{b}$-value corresponds to the maximum value that $\kappa_{X}$ can reach (e.g. Barillé et al., 1997; Robert et al., 2006) and the X-value is the phytoplankton concentration.

\subsection{Hindcasting approach (1960 to 2014)}

The model was first used to backwards simulate yearly growth and reproductive traits of Pacific oysters since their introduction in 1960, with the aim of detecting the emerging conditions that permitted a better reproductive success in the Bay of Brest. To take into account enough interindividual variability, the model simulated 180 individual trajectories each year. Each individual differs in terms of initial condition values (E, $E_{R}$, and V; Table A.2). This "test sample" was created by pooling all the individuals initially sampled during our 6-year monitoring program $(n=6 \times 30=180$ individuals).

Since SST data were not available for the whole period, daily water temperature in the Bay of Brest was calculated between January 1960 and December 2014 by using daily recordings of the air temperature and a logistical regression obtained by the SSlogis function implemented in the R software (Appendix B; Fig. B.1). Clearly, using air temperature instead of direct seawater temperature is not ideal, but Pacific oysters in the Bay of Brest always live in shallow embayments where air temperature and water temperature are relatively well correlated (see correlations obtained over the 6 years of monitoring).

For the hindcasting analyses, we also paid particular attention to the periods before and after 1995, since climatologists identified a first temperature shift (in the western English Channel) due to climate change in this year (L'Hévéder et al., 2017).

As phytoplankton concentrations (food source) were also not available over this long historical period, we used our 6-year monitoring as six potential phytoplankton scenarios (i.e. scenarios A to F correspond to the phytoplankton concentrations and variations observed from 2009 to 2014 respectively, Table 1). Briefly, the six years were defined by the onset of the spring bloom (from early to late) and the level of the summer bloom (from low to high). Therefore, six hindcasting analyses 
were performed from 1960 to 2014 and reproductive success was analyzed under these six potential phytoplankton scenarios.

Table 1: Identification and characteristics of the six phytoplankton scenarios. The date of the first bloom is defined when a peak of 1000000 cells/L is reached. The onset of the main spring bloom is classified into three categories: Early, Normal, and Late, when the first bloom is observed in March, April, and May/June, respectively. Summer blooms are also classified into three categories according to their concentrations and occurrences.

\begin{tabular}{|r|r|c|c|r|r||}
\hline Year & First yearly bloom date & $\begin{array}{c}\text { Max. concentration } \\
\text { of bloom (cells/L) }\end{array}$ & $\begin{array}{c}\text { Onset of spring } \\
\text { blooms }\end{array}$ & $\begin{array}{c}\text { Summer } \\
\text { blooms }\end{array}$ & Name \\
\hline 2009 & 2 April & 4900000 & Normal & Normal & A \\
2010 & 28 April & 3500000 & Normal & Normal & B \\
2011 & 4 May & 2000000 & Late & Low & C \\
2013 & 3 May & 3800000 & Late & High & D \\
2014 & 13 June & 4600000 & Late & High & E \\
\hline
\end{tabular}

2.7. Forecasting approach (2040 to 2100)

Projections of oyster reproduction patterns were made for the 2040-2100 period. The same pool of 180 individuals used for the hindcasting approach and the same six scenarios of phytoplankton concentration were used. Monthly atmospheric temperatures $\left(\mathrm{T}_{\mathrm{Atm}}\right)$ were obtained from regional climatic models, following two IPCC Representative Concentration Pathways (RCP): RCP8.5 and RCP2.6. The RCPs are the latest generation of scenarios that provide inputs to climate models and there are four reference scenarios of changes in radiative forcing for the 2006-2300 period (Appendix C; Fig. C.1). RCPs are temporally and spatially explicit (resolution of approximately 60 kilometers) and provide a quantitative description of concentrations of climate change pollutants and their radiative forcing in the atmosphere (Moss et al., 2010). In this study, we used the two extreme scenarios: RCP8.5 and RCP2.6. A Taylor diagram (see next section) was devised to choose the most suitable model (the CNRM-CM5 model) for our study site among the 14 existing climatic models for each RCP scenario (Fig. C.2). For each scenario, monthly SST was calculated from the monthly $\mathrm{T}_{\text {Atm }}$ using linear regression (see Appendix B; Fig. B.2). 


\subsection{Statistical analysis}

Simulations and observed data were compared using a Taylor diagram. This diagram provides a statistical summary of the agreement between a reference (field data) and modeling results (Taylor, 2001). Three statistical measures are associated with the Taylor diagram: root-mean-square (RMS) difference, normalized standard deviation and Pearson correlation. To compare temperature patterns of climatic scenarios (past, present, and future), we distinguished annual SST and summer SST, since reproductive success is partly dependent on summer seawater temperature. For the historical reconstruction, an analysis of variance (ANOVA) was used to test the null hypothesis of no difference in annual SST or summer SST according to a time factor (before and after ocean warming in 1995). An analysis of variance (ANOVA) with Welch correction was used to test the null hypothesis of no difference in spawning date according to the six phytoplankton profiles for the three temperature conditions over each annual time series (past, and RCP2.6 and RCP8.5 scenarios). Finally, linear regression and Pearson correlation were used to test the trends in reconstructed and predicted life history traits, as well as their relationships with environmental forcing (Appendix D). All statistical analyses were performed using R 3.2.2 software (R Core Team, 2018).

\section{Results}

\subsection{Model validation}

Throughout the six simulated years, there was a good fit between observations and simulations in oyster growth, with a mean correlation coefficient up to 0.9 and a normalized standard deviation close to 1 (Fig. 3). 


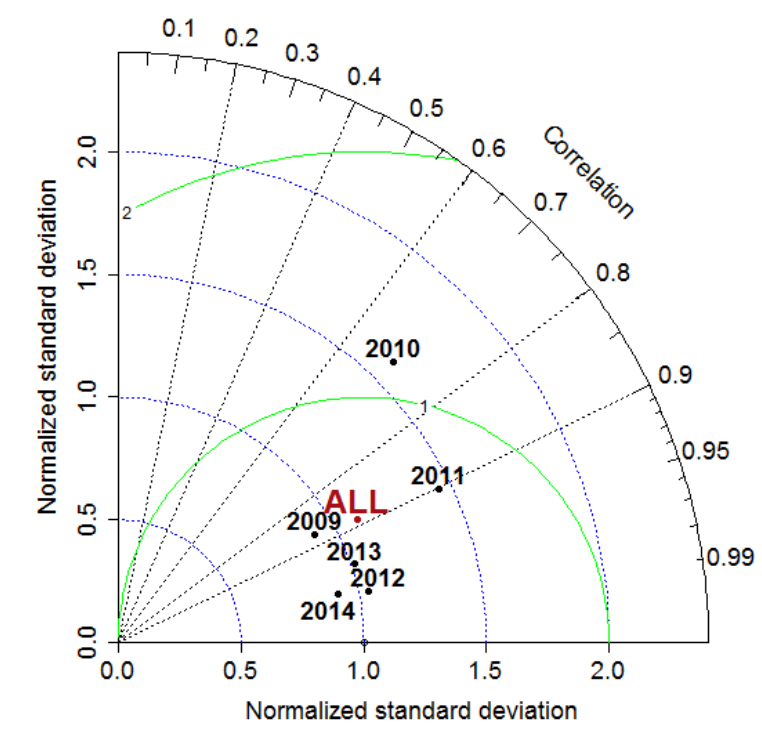

Figure 3: Taylor diagram providing the normalized standard deviation, the Pearson correlation and the root mean square difference (green line) between simulated and observed dry flesh mass. Each simulated year is represented by a black dot. The mean of these 6 years is represented with a dark red dot.

Each year, from March to August, the simulated DFM rose steadily due partly to the increase in gonad weight during active gametogenesis. The highest DFM value was reached prior to spawning (Fig. 4). The simulated spawning date agreed with observations over the entire 6-year period. After spawning (all years except 2013), the slow decrease in weight observed during the autumnal period was accurately reproduced by the model. For the year without spawning (year 2013, see above), the model satisfactorily captured the gonad resorption processes (slow decrease in gonad weight). In comparison to the observed data, the maximum DFM value simulated were similar in 2011, 2012, and 2013. There was a slight overestimation for years 2010 and 2014 and a slight underestimation for 2009 (Fig. 4. 


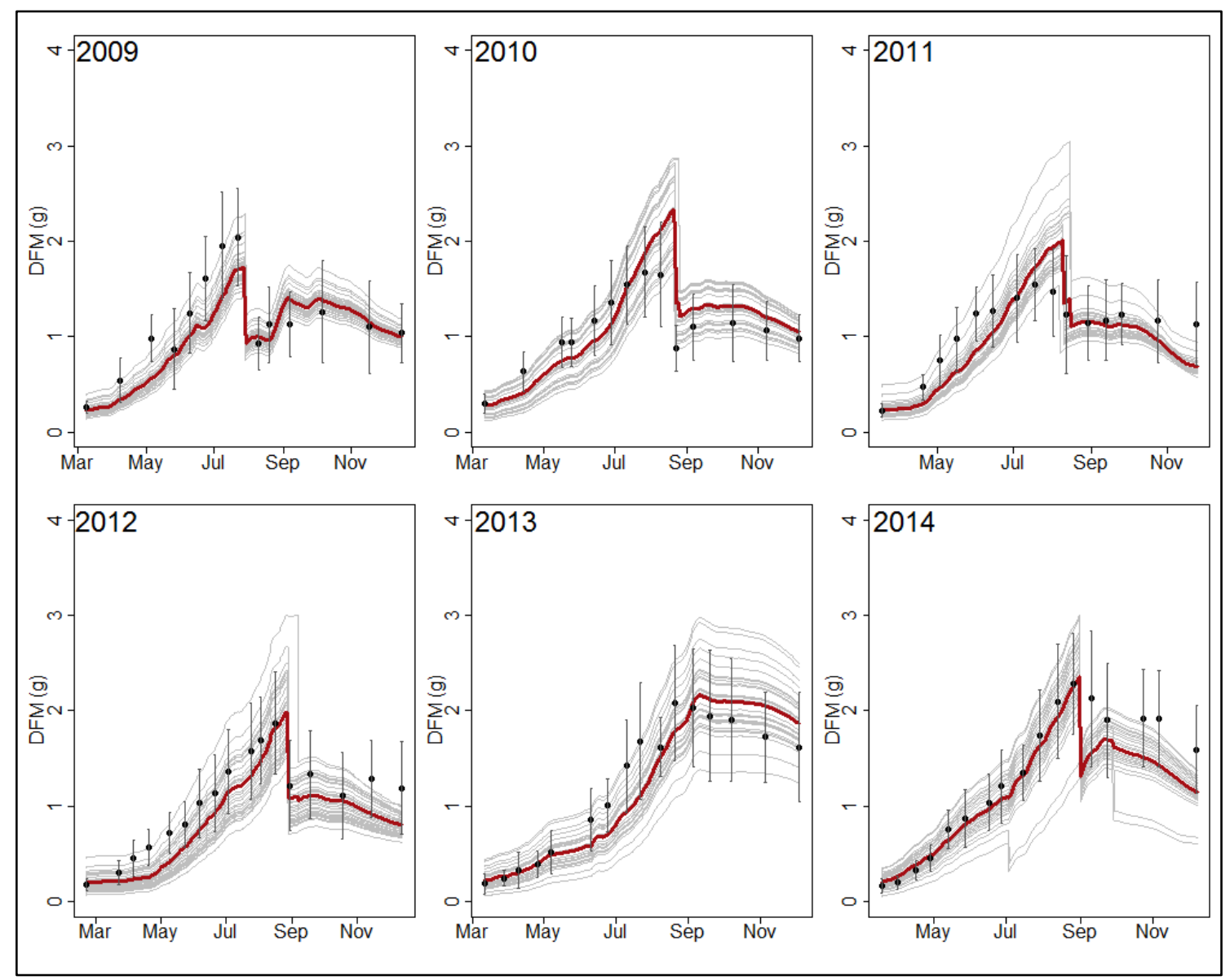

Figure 4: Oyster growth and spawning simulations obtained by the DEB model compared with observed data from 2009 to 2014 (DFM = Dry Flesh Mass). Observed DFM is represented by black dots with standard deviation bars $(\mathrm{n}=30)$. Grey lines represent individual growth trajectories simulated by the model. The dark red bold line represents the mean of the 30 trajectories.

Concerning spawning behavior, the observed DFM data (sharp decrease in DFM) showed that spawning took place in July in 2009 and 2011, in August in 2010 and 2012 and in early September in 2014, whereas there was no spawning at all in 2013. The model also succeeded in capturing this type of precise phenomenon. In addition, simulations obtained from individual trajectories $(\mathrm{n}=30)$ highlighted three potential types of spawning events (Fig. 4):

- Synchronous and massive events (notation: S), where all individuals spawn at the same time within an interval of a few days: early in the season (mid-July in 2009) or late in the season (end of August in 2010 and 2012).

- Multiple spawning events (notation: MS), showing some individuals that spawn at different times within the season. This is the case in 2014, where two periods of spawning events can 
be observed in the simulation curves: 28 individuals spawn once on 1 September whereas the other two individuals spawn twice, first on 3 July and then on 1 October.

- Lack of spawning or "no-spawning" events (2013, notation: NO), showing an absence of DFM loss followed by a slow decrease during autumnal regression.

Concerning the fecundity, which was represented by oocyte production at spawning time, the simulation trends mainly coincided with the observed data (Fig. 4).

\subsection{Model application: evolution in the reproductive strategy of $C$. gigas from 1960 to 2100}

\subsubsection{Environmental conditions from 1960 to 2100}

In the hindcasting analyses (1960 to 2014), the reconstructed mean annual SST (1960-2014) showed a significant increase over the last 50 years (Fig. 5, linear regression: $\mathrm{r}^{2}=0.36, \mathrm{P}<0.001$ and slope $=0.02^{\circ} \mathrm{C}_{\text {year }^{-1}}$ ) as the reconstructed mean summer SST for the same period (Fig. 5, linear regression: $\mathrm{r}^{2}=0.15, \mathrm{P}<0.005$ and slope $=0.02^{\circ} \mathrm{C}$ year $\left.^{-1}\right)$. More specifically, the mean annual SST and summer SST were significantly higher during the period 1995-2014 (Fig. 5, ANOVA: d.f.=1, $\mathrm{P}<0.001)$

In the forecasting analyses, the projected mean annual and summer seawater temperature showed little or no increase over the next 100 years under RCP2.6 (Fig. 5, Annual SST: linear regression: $\mathrm{r}^{2}=0.05, \mathrm{P}<0.001$ and slope $=0.00614^{\circ} \mathrm{C}$ year ${ }^{-1}$, Summer SST: linear regression: $\mathrm{r}^{2}=$ 0.04, $\mathrm{P}=$ n.s. and slope $=-0.01{ }^{\circ} \mathrm{C}$ year $\left.{ }^{-1}\right)$, whereas a large increase was predicted for the next 100 years under RCP8.5 (Fig. 5, Annual: linear regression: $\mathrm{r}^{2}=0.74, \mathrm{P}<0.001$ and slope $=0.04^{\circ} \mathrm{C}$ year ${ }^{-1}$; Summer: linear regression: $\mathrm{r}^{2}=0.41, \mathrm{P}<0.001$ and slope $=0.04^{\circ} \mathrm{C}$ year $\left.^{-1}\right)$. Note that differences between RCP 2.6 and RCP 8.5 would occur after 2070, but would be less pronounced in summer than during the rest of the year. 


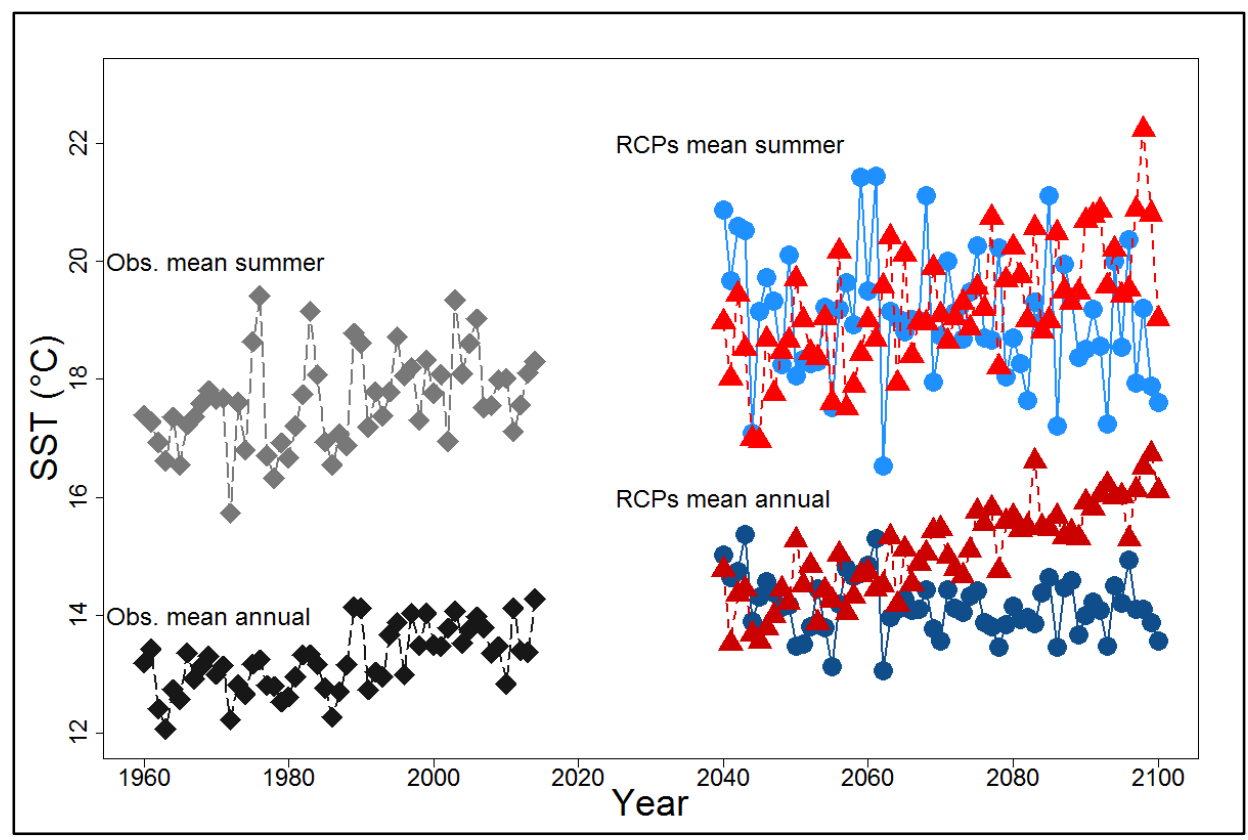

Figure 5: Historical and forecasted mean annual and mean summer Sea Surface Temperature (SST) in the Bay of Brest; 1960-2014: black and grey diamonds, respectively; 2040-2100: RCP2.6 in dark blue and pale blue circles and RCP8.5 in dark red and red triangles, respectively.

\subsubsection{Simulated phenological changes}

Concerning the hindcasting approach (from 1960 to 2014, Fig. 6a), the mean spawning date ranged from 12 August (phytoplankton-scenario A) to 19 September (phytoplankton-scenario F). For the forecasting approach (from 2040 to 2100), under the RCP2.6 scenario (Fig. 6b), which is considered the lowest emissions scenario, the mean spawning date varied from 4 August (phytoplankton-scenario A) to 6 September (phytoplankton-scenario F), which was very similar to the hindcasting results (Fig. 6a). Under the RCP8.5 scenario (Fig. 6c), considered as the warmest scenario, the mean spawning date varied from 1 August (phytoplankton-scenario A) to 10 August (phytoplankton-scenario F), which was earlier than the historical analyses and the RCP2.6 scenario.

Phenological changes were simulated in the past and RCP8.5 climatic scenarios. For half of the phytoplankton scenarios (A, C, and E), an advanced spawning date on the period 1960-2014 was simulated in the range of $0.1-0.25$ day $^{-1}$ (Fig. 6a). Concerning the period 2040-2100, an advanced spawning date was simulated in the range of 0.05 to 1.02 day y-1 with RCP8.5 scenario (Fig. 6c), whatever the phytoplankton scenarios tested. No phenological changes was simulated under the RCP2.6 scenario (Fig. 6b). Correlations between spawning dates and summer SSTs were found for 
many scenario configurations (Table D.1). In each case, the correlation highlighted an earlier spawning date with an increase of summer SST.

Last, figure 7 illustrates that for both hindcasting and forecasting simulations seasonal phytoplankton profiles had more impact on the spawning date than temperature (Fig. 7), except for the phytoplankton scenario $\mathrm{F}$ where the variability du to climate seems stronger. Globally the variability in the spawning date associated with the bloom (ANOVA: $\mathrm{df}=5, \mathrm{P}<0.001$ ) exceeds the variability associated with climate scenarios (ANOVA: $\mathrm{df}=1, \mathrm{P}>0.001$ ).

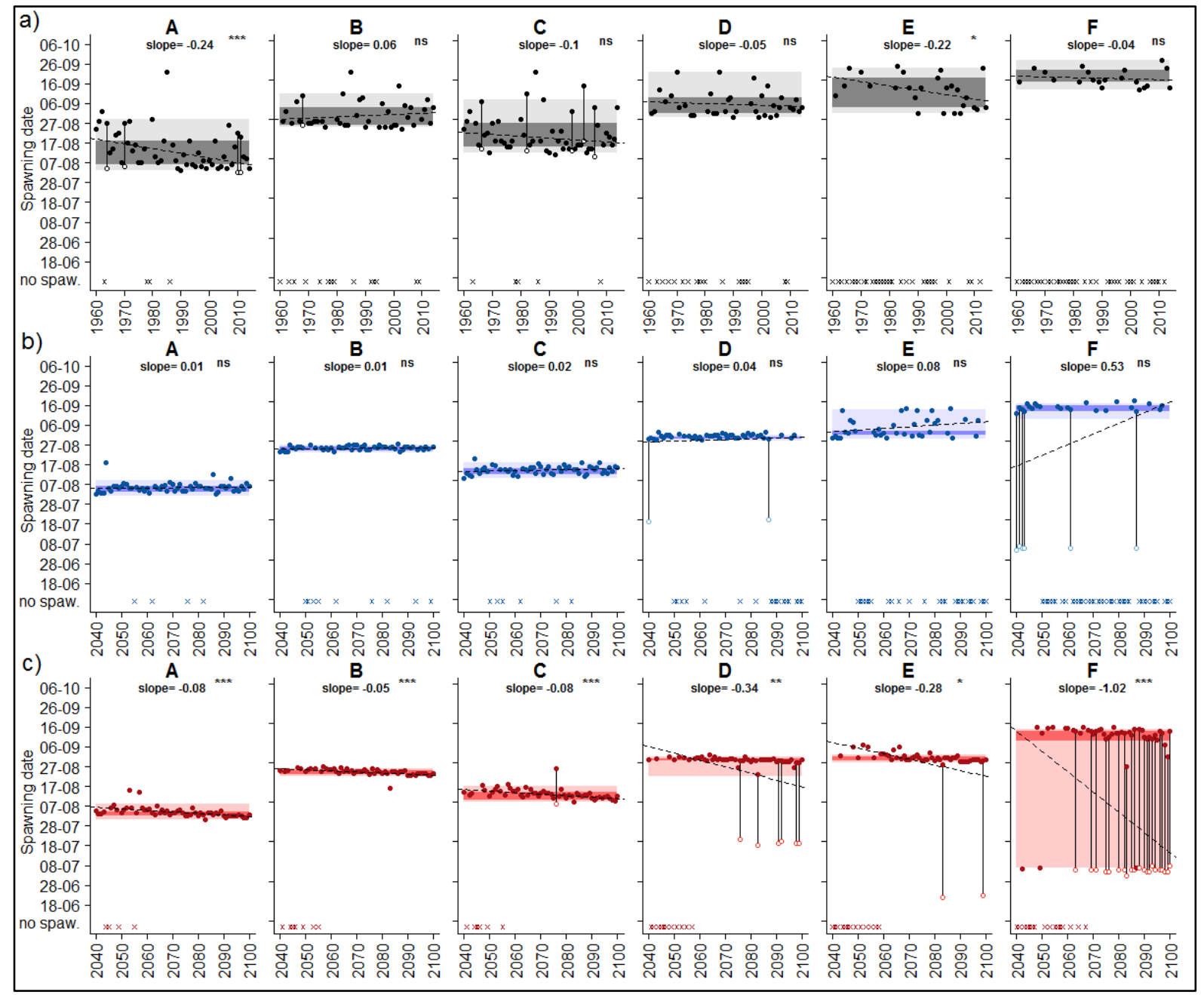

Figure 6: Simulated spawning behavior of the Pacific oyster in the Bay of Brest. (a) Results from hindcasting (from 1960 to 2014) and forecasting analyses under (b) RCP2.6 (blue) and (c) RCP8.5 (red), for the six phytoplankton scenarios (A to F). Three kinds of spawning can be observed: (1) Synchronous and massive (S) events (filled colored dots); (2) Asynchronous and multiple spawning (MS) events (open colored linked dots represent min and max spawning dates) and (3) Lack of spawning (crosses at the bottom of the plot). The dashed black line represents the linear regression of spawning date on time over the entire period. The slope of the regression is given in each graph with its level of significance (n.s. not significant, $* \mathrm{P}<0.05$, ** $\mathrm{P}<0.01$, *** $\mathrm{P}<0.001$ ). 


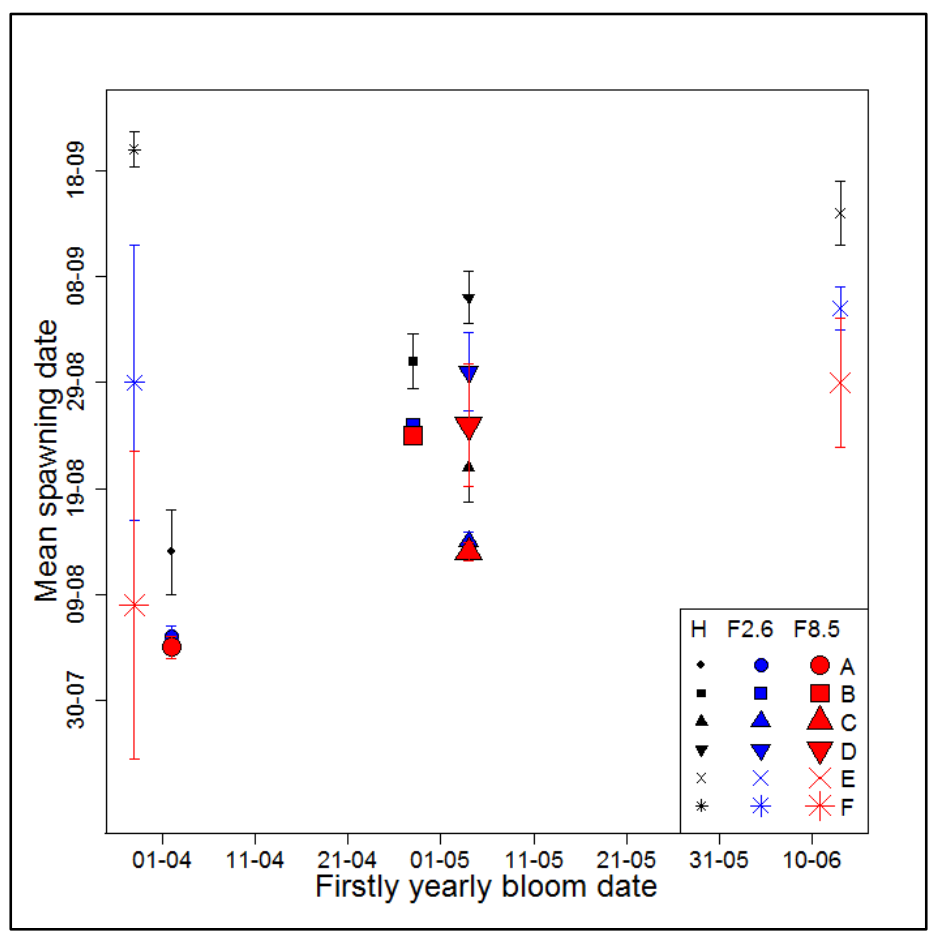

Figure 7: Effect of first bloom date on the first spawning event of the Pacific oyster in the Bay of Brest under each phytoplankton scenario (A to $\mathrm{F}$ represented by a symbol) and climatic scenarios (H=Hindcast in black; F2.6=Forecast RCP2.6 in blue; F8.5= Forecast RCP8.5 in red). Standard deviation show the level of synchronicity in the spawning date. A long bar indicates several asynchronous events such as observed under profile F.

\subsubsection{Spawning behavior}

Another point highlighted by our results concerns the type of spawning (NO, S or MS) according to climatic and phytoplankton scenarios (Fig. 6 and Fig. 8). From 1960 to 2014, nospawning events (NO) were more frequent before 1995 for all the phytoplankton scenarios tested. From 1995 to 2014, NO events progressively decreased, and disappeared completely under RCP8.5 after 2070. In contrast, under RCP 2.6, an increase of the NO events is simulated after 2070 and reached a frequency similar to the ones simulated after 1995 in the hindcasting analyses. Only few multiple spawning events (MS) were simulated under the hindcasting analyses with phytoplankton scenarios A and C (Fig. 8). Most of the events were synchronous (S) under RCP2.6, MS events were rare for all phytoplankton scenarios, whereas they became increasingly frequent under the RCP8.5 scenario at the 2070 horizon, in particular under phytoplankton scenarios D and F. 


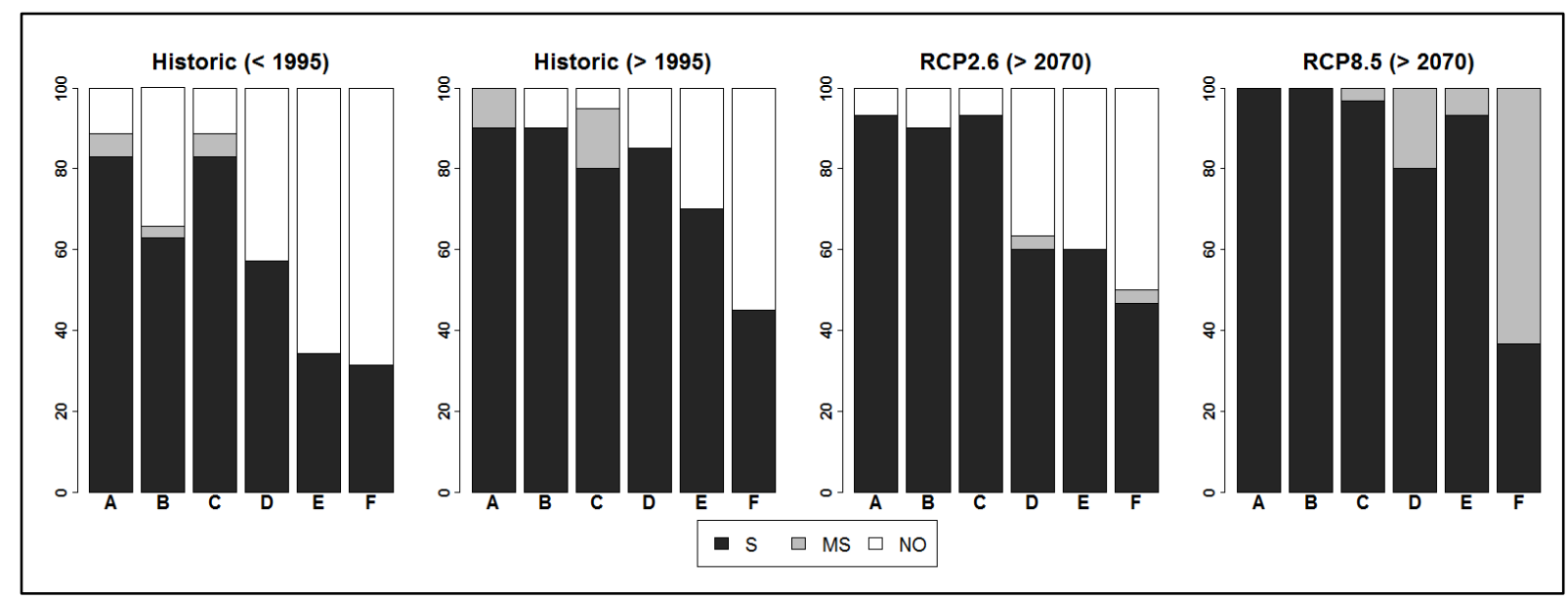

Figure 8: Percentage of the spawning strategy simulated in $C$. gigas according to phytoplankton scenarios (A to F) for the hindcasting and forecasting approaches. (S) Synchronous spawning, all individuals spawn completely and simultaneously, (MS) multiple spawning, individuals spawn at different dates or spawn twice, (NO) no spawning occurred. The historical period was divided into two periods, before and after 1995, following the occurrence of a shift in mean annual temperature, as observed in Figure 5.

\subsubsection{No real change in fecundity}

Figure 9 shows the annual mean fecundity of individuals according to the phytoplankton/climatic scenarios. Significant differences in fecundity existed between phytoplankton scenarios (ANOVA: d.f. $=5, \mathrm{P}<0.001$ ), with lower values in scenarios $\mathrm{A}, \mathrm{B}$, and $\mathrm{C}$ and higher values in scenarios D, E, and especially F. No decadal trends were observed either in the past or in RCP2.6 scenarios. Under the RCP8.5 scenario, all phytoplankton profiles except F presented an increase of the fecundity but with very low slope values. A significant correlation was also found between the individual fecundity and the summer SST (except for the phytoplankton scenario F, see Table D.2). 


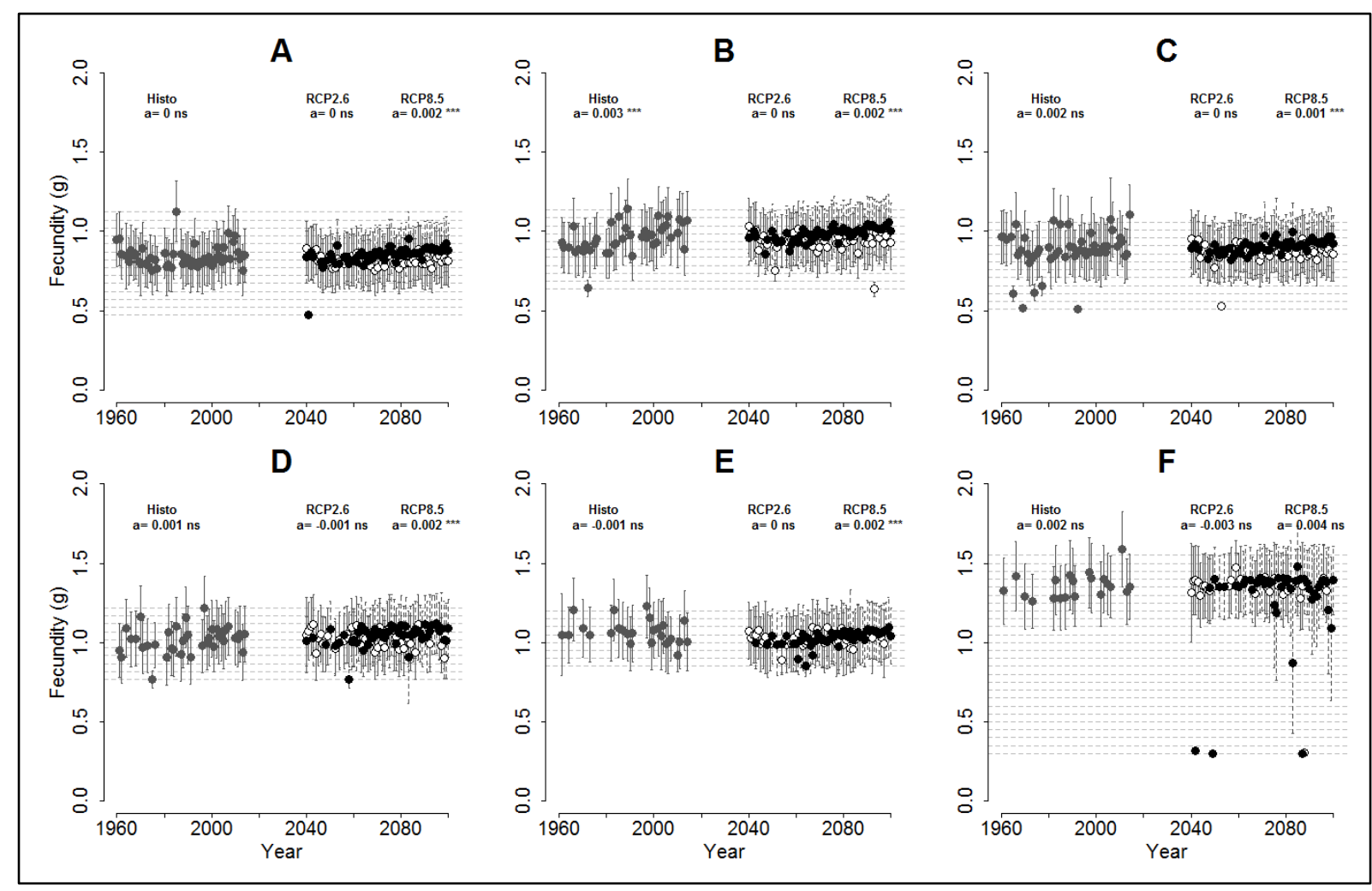

Figure 9: Fecundity of $C$. gigas simulated according to environmental scenarios. Grey dots: hindcasting results from 1960 to 2014, white and black dots: forecasting results from 2040 to 2100 under RCP2.6 and RCP8.5 scenarios, respectively. Results are given for the six phytoplankton profiles (A to F). The slope of the linear regression of fecundity over the entire period is given in each graph with its significance level (n.s. not significant, $* \mathrm{P}<0.05$, ** $\mathrm{P}<0.01$, *** $\mathrm{P}<0.001$ ). 


\section{Discussion}

This study was the first application of the oyster-DEB model in the Bay of Brest, the northernmost area in France where C. gigas currently forms massive biogenic reefs, some 40 years after its introduction in Europe for aquaculture purposes. Our objective was to identify when environmental conditions became more favorable for the reproductive success of this species (hindcasting approach) and what might be expected concerning its reproduction at the 2100 horizon (forecasting approach). We highlighted three major results: first, the unexpected complex coupling effect of phytoplankton dynamics and temperature cycle on the reproductive process; second, the progressive increase of spawning occurrences over time; and third, the potential phenological change in spawning date, especially under the RCP8.5 "business as usual" scenario.

\subsection{Calibration of the oyster-DEB model in a new environment}

Compared to the Bay of Bourgneuf (Thomas et al, 2016), where a similar model was applied, the Bay of Brest presents higher phytoplankton concentrations, especially during summer, leading to potential phenotypic plasticity to these local conditions (Dutertre et al., 2016). In order to apply the model to this new environment, some parameters were re-calibrated: two parameters implicated in feeding processes and two parameters implicated in spawning processes.

For feeding processes, the recalibration concerned the food half saturation coefficient $\left(\mathrm{X}_{\mathrm{k}}\right)$ and the assimilation efficiency $\left(\kappa_{\mathrm{X}}\right)$. DEB models for filter-feeders commonly use a single value of assimilation independent of the quality/quantity of phytoplankton (e.g. Bernard et al., 2011; Thomas et al., 2016). However, many laboratory experiments have shown that assimilation efficiency is expected to vary according to phytoplankton ingested by oysters, both in terms of quality and quantity (e.g. Barillé et al., 1997; Robert et al., 2006). In case of high blooms, keeping $\kappa_{\mathrm{X}}$ constant systematically led to an overestimation of oyster growth in the Bay of Brest. Thus, we introduced a decreasing relationship of assimilation efficiency with phytoplankton concentration. As recently discussed for blue mussels (Picoche et al, 2014), in situ experiments concerning the dietary regime of oysters would be a real contribution to the improvement of this point in future studies. 
Reproducing the spawning traits over the 6 years of monitoring, particularly the spawning dates, was a key step making it possible for us to study C. gigas phenology. Particular attention was therefore paid to the two values that are known to control spawning processes: the temperature threshold $\mathrm{T}_{\mathrm{S}}$ and the gonado-somatic index (GSI). These two parameters are sufficient to roughly but simply capture all the environmental and endogenous factors that control spawning, as described initially by Sastry (1979). Considering a temperature threshold as a trigger for spawning is largely accepted for this species (e.g. Bernard et al., 2011; Cardoso et al., 2013). However, depending on its habitat, but also on the way water temperature is measured (whether or not this is high frequency, in phase with tidal cycle, etc.), values used for $\mathrm{T}_{\mathrm{S}}$ can vary between $17^{\circ} \mathrm{C}$ (Castaños et al. 2009) and $20^{\circ} \mathrm{C}$ (Pouvreau et al. 2006). More recently, Thomas et al. (2016) used a $19^{\circ} \mathrm{C}$ threshold in their study. In hatcheries, technicians know that free-spawning events can occur for $C$. gigas if the water temperature in the tanks exceeds $18.5^{\circ} \mathrm{C}$. To avoid accidental spawning in broodstock conditioning, they carefully maintain water temperature below $18^{\circ} \mathrm{C}$. The calibration procedure for the Bay of Brest used in the present study gave a threshold value $\mathrm{T}_{\mathrm{S}}$ of $18.7^{\circ} \mathrm{C}$, which is very close to this empirical hatchery knowledge. Concerning the GSI, values generally vary between 0.40 and 0.60 in Crassostrea gigas according to previous studies (Kang et al., 2003; Cardoso et al., 2007). In the present study, we also found that spawning date predictions were sensitive to the GSI value, especially since this parameter is calculated as a ratio between two state variables. A single value of 0.47 , for the whole 2009-2014 period, allowed the model to accurately capture the observed spawning dates in the Bay of Brest.

\subsection{Further improvements}

As in previous applications of the oyster DEB model (e.g. Bernard et al., 2011; Thomas et al., 2016), our model correctly mimics growth and reproduction patterns observed in the field in the environment of the Bay of Brest (Fig. 4). Simulated spawning dates were always within the observed ranges and the model was able to simulate the three categories of spawning observed: synchronous spawning (2009-2012), multiple spawning (2014) or no-spawning events (2013). Such a spawning strategy was suspected to occur in the field, but has remained difficult to demonstrate easily (see 
Bernard et al., 2016). Clearly, many discrepancies remain between the simulations and observations and many of these could probably be explained by the simplifications made during our modeling strategy. For example, we reproduced part of the observed variability by considering 30 simulated individuals each year. However, except for their initial values $\left(\mathrm{V}, \mathrm{E}, E_{R}\right)$, the individuals do not differ in terms of DEB parameters. Future work could include the introduction of variability in some key parameters to mimic potential genetic variability within the population (Gangnery et al., 2004).

Concerning the forecasting approach, using IPCC model outputs is supposedly the best way to obtain more realistic temperature dynamics under different climatic scenarios. However, regarding the phytoplankton scenarios, the method used here needs to be improved in future studies. After having considered several options and testing them, it appeared that using the 6 years of phytoplankton dynamics acquired from 2009 to 2014 as six different phytoplankton scenarios for past and future simulations was the best solution. Nevertheless, satisfactory models of phytoplankton dynamics at the regional scale are also currently being developed (e.g. Lévy et al., 2015; Niu et al., 2015). Of course, such models are strongly dependent on area characteristics and require accurate physical, biogeochemical, and biological data. Such models are not yet available for the Bay of Brest, but coupling our approach to these models will be a promising direction for further work.

\subsection{Larger and earlier spawning in the future}

Temperature is known to be a major driving factor for gametogenesis. It not only acts as a trigger for spawning but also as a "cumulative" function that controls gametogenesis (Sastry, 1979; Barber \& Blake, 1991). This mechanism is taken into account in the oyster-DEB model as temperature controls all metabolic rates following the Arrhenius function. Here, for all phytoplankton scenarios tested, we have shown that the recent increase of seawater temperature promoted spawning events after 1995. Establishment of oysters in the Bay of Brest was temperature-limited prior to 1995, as has been demonstrated in other areas on the French Atlantic coast (Dutertre et al., 2010; Thomas et al., 2016). It also appeared from our forecasting approach that this phenomenon would be enhanced in the future under the RCP8.5 scenario, for which no-spawning events would completely disappear after 2070. Conversely, under the RCP2.6 scenario, their frequency would be maintained, or even 
increased, after 2070. Indeed, the RCP2.6 scenario would lead to a progressive return to "normal temperature values" and spawning behavior obtained under this scenario after 2070 would be similar to that observed in the hindcasting analyses before 1995 .

If the occurrence of spawning is guaranteed under warmer conditions, onset of spawning would also be affected. Over the 140-year period tested here (using RCP8.5), the spawning phenology of $C$. gigas would be significantly earlier under five of the six phytoplankton scenarios $(\mathrm{A}=-0.07$ day $\mathrm{y}^{-1}, \mathrm{~B}=-0.05$ day $\mathrm{y}^{-1}, \mathrm{C}=-0.07$ day $\mathrm{y}^{-1}, \mathrm{D}=-0.34$ day $\mathrm{y}^{-1}$, and $\mathrm{F}=-1.00$ day $\mathrm{y}^{-1}$; Table D.1.1). This modeling result is in agreement with the existing literature. Studies on the reproductive phenology of terrestrial and aquatic species have often concluded that reproduction processes are advanced by rising temperatures (Parmesan \& Yohe, 2003). Although there have been less studies focused specifically on marine invertebrates, they have led to the same conclusion. Martin \& Planque (2006) showed for instance, in the English Channel, that the date of the first observation of zoeae was negatively correlated with increasing sea temperature. In a more southern location, the Bay of Bourgneuf, Thomas et al (2016) showed that the spawning date of $C$. gigas was advanced by 4 day $\mathrm{y}^{-1}$ after the 1990s. Similarly, in the Wadden Sea, Philippart et al (2003) demonstrated that the spawning date of the bivalve Macoma baltica was earlier, with an average advancement of 0.44 day $\mathrm{y}^{-1}$ since 1970 and a phenological advancement of 0.99 day $\mathrm{y}^{-1}$ since 1985 .

\subsection{A question of timing: unexpected interactions between food and temperature}

Although food availability and temperature have been well studied and are both known to regulate reproduction in marine invertebrates (e.g. Olive 1992, 1995; Reitzel et al. 2004), relatively little is understood about the temporal coupling effects of food variability and temperature seasonal cycle. It is assumed that a temperature threshold is the input signal for the spawning window and that phytoplankton is the driver that first impacts the growth of an individual and then allows (or not) the allocation of sufficient energy for the reproduction buffer. Starr et al. (1990) concluded that a major advantage of phytoplankton as a spawning cue is that it integrates various environmental parameters indicating favorable conditions for larval success. The influence of seasonal phytoplankton blooms on oyster reproduction is described in many studies (e.g. Mori, 1979; Deslous-Paoli, 1982; Ruíz et al., 
1992; Kang et al., 2000; Enriquez-Diaz et al., 2009), but not in terms of phasing with the seasonal temperature cycle. Such coupling effects were studied in more detail with a DEB approach by Bernard et al., 2011 and Thomas et al., 2016. Our study gives further insights into this complex coupling/phasing effect. To summarize the results obtained here, Table 2 provides an overview of all the hindcasting and forecasting simulations. According to the year, phytoplankton dynamics can be synchronized with the temperature annual cycle (cases of "Normal blooms", scenarios A, B, C) or more desynchronized in the case of early blooms (scenario F) or late blooms (scenarios E, D). Such phasing/dephasing will control, to a certain extent, the type and the onset of spawning, ranging from the absence of spawning (NO) to potentially two spawning events during the summer (MS). This summary table also shows the trends according to climatic scenarios.

Table 2: Overview and summary of all results obtained through hindcasting and forecasting simulations concerning the spawning occurrence according to environmental conditions of phytoplankton (described in Table 1) and summer temperature (Cold: $\left\langle 13^{\circ} \mathrm{C}\right.$; Normal: $\angle 14^{\circ} \mathrm{C}$; Hot: $>14^{\circ} \mathrm{C}$ ). Different phasing between phytoplankton seasonal blooms and temperature values (especially in early summer) gave different responses in terms of spawning events: no occurrence of spawning (NO), synchronous spawning ( $\mathrm{S}$, late to precocious), and multiple spawning events (MS).

\begin{tabular}{|c|c|c|c|c|}
\hline & & \multicolumn{3}{|c|}{ Level of the summer temperature } \\
\hline $\begin{array}{l}\text { Date of } \\
\text { the } \\
\text { bloom }\end{array}$ & $\begin{array}{c}\text { Level of } \\
\text { the } \\
\text { bloom }\end{array}$ & Cold & Normal & Hot \\
\hline Early & $\begin{array}{l}\text { High } \\
(\mathbf{F})\end{array}$ & $\begin{array}{c}\text { NO } \\
(<1995 \& \text { RCP 2.6) }\end{array}$ & $\begin{array}{c}\text { S (late) } \\
(\mathrm{RCP} 2.6)\end{array}$ & $\begin{array}{c}\text { MS (precocious + late) } \\
\quad(2014 \text { \& RCP 8.5) }\end{array}$ \\
\hline Normal & $\begin{array}{l}\text { Normal } \\
(\mathbf{A}, \mathbf{B}, \mathrm{C})\end{array}$ & $\begin{array}{c}\text { NO to } S \text { (late) } \\
(<1995)\end{array}$ & $\begin{array}{c}\text { S (normal) } \\
(2010 / 2011)\end{array}$ & $\begin{array}{c}\text { S (precocious) } \\
(2009 \& \text { RCP 8.5) }\end{array}$ \\
\hline Late & $\begin{array}{l}\text { High } \\
(\mathrm{D}, \mathrm{E})\end{array}$ & $\begin{array}{c}\text { NO } \\
(2013 \&<1995)\end{array}$ & $\begin{array}{c}\text { S (late) } \\
(2012 \& \text { RCP 2.6) }\end{array}$ & $\begin{array}{c}\mathbf{S} \text { (precocious) to MS } \\
(\mathrm{RCP} 8.5)\end{array}$ \\
\hline
\end{tabular}

Modeling approaches of the primary production within the Bay of Brest (but also long-term mesocosms experiments) are now required to further study this question. The nature, onset, and amplitude of phytoplankton blooms are modified by global warming (e.g. Edwards \& Richardson, 2004). For example, in the western Scheldt Estuary, an earlier bloom onset was reported with increasing temperature over the last 30 years (Kromkamp \& Van Engeland, 2009). Mesocosms experiments also showed that the degree of response varies among taxonomic groups. For instance, 
spring blooms of diatoms, which are a principal food source for oysters, are assumed to remain relatively fixed in time as they are dependent on light intensity, which is generally presumed as invariant with global warming (Sommer et al. 1986; Edwards \& Richardson, 2004). Nevertheless, cloud cover is expected to increase with climate change (known as "global dimming"; Stanhill \& Cohen, 2001; Liepert, 2002; Roderick \& Farquhar, 2002). This "global dimming" could alter the timing and magnitude of phytoplankton blooms (Sommer et al. 2012; Winder et al. 2012), leading to potential mismatches. Temperature elevation has also been shown to have a strong negative influence on cell size and peak biomass of phytoplankton (Sommer et al. 2012; Winder et al. 2012). These studies, along with others (e.g. Moran et al. 2010; Hoegh Guldberg \& Bruno, 2010), predict a gradual shift towards smaller primary producers and reduced productivity in a warmer ocean. Clearly, there is a number of mechanisms associated with climate change that may have an effect on the timing, quality, and magnitude of phytoplankton blooms and that may have direct consequences for the reproductive success of filter feeders. In the Bay of Brest, there was some evidence that the timing of phytoplankton blooming or phytoplankton peaks have already been modified and/or shifted (e.g. Cloern, 2001). However, these trends were not included, at the moment, in our phytoplankton scenarios. Such modifications should be taken into account in future studies.

\section{Conclusion}

Understanding the responses of species to climate change is one of the most pressing issues biologists face today. Here, by using a modeling tool (DEB model) coupled to IPCC scenarios, our study provides new insights into the reproductive responses of a common and widespread marine invertebrate, the Pacific oyster, with respect to global warming. We have demonstrated that the increase in seawater temperature has allowed more spawning events in the Bay of Brest since 1995 and that this phenomenon would be further enhanced in a warmer world (RCP8.5 scenario), in association with a progressively earlier onset of spawning. However, seawater temperature was not the only driving factor for changes in terms of spawning phenology. The potential variability in the seasonal pattern of phytoplankton blooms also played a predominant role. The phasing of phytoplankton seasonal blooms with the temperature seasonal cycle should lead to significant modifications in the reproductive pattern (no-spawning versus multiple spawning events), which may 
be decisive for the subsequent recruitment dynamics. Therefore, our results show that predicting temperature conditions in the future (IPCC scenarios) would not be sufficient to accurately predict the reproductive success of filter-feeding species. Further research focused on phytoplankton dynamics under different climate change scenarios is now required in the Bay of Brest, a remarkable phytoplankton-rich environment at the northern limit of $C$. gigas populations in France.

\section{Acknowledgements}

This research was funded by a grant from Brittany region and by the University of Western Brittany (UBO). The authors are grateful to the Ifremer staff of the RESCO and VELYGER networks, through which the field data were gathered (https://wwz.ifremer.fr/velyger/Acces-aux-Donnees/Radede-Brest). 


\section{References}

Barber, B.J. \& Blake, N.J. (1991) Reproductive physiology. In SHUMWAY, SE. (Ed.). Scallop: biology, ecology and aquaculture. Amsterdam: Elsevier.

Barillé, L., Héral, M. \& Barillé-Boyer, A.L. (1997) Modélisation de l'écophysiologie de l'huître Crassostrea gigas dans un environnement estuarien. Aquatic Living Resources, 10(1), 31-48.

Beiras, R., Pérez Camacho, A. \& Albentosa, M (1994) Comparison of the scope for growth with the growth performance of Ostrea edulis seed reared at different food concentrations in an open-flow system. Marine Biology, 119, 227-233.

Bernard, I., De Kermoysan, G. \& Pouvreau, S. (2011) Effect of phytoplankton and temperature on the reproduction of the Pacific oyster Crassostrea gigas : Investigation through DEB theory. Journal of Sea Research, 66(4), 349-360. doi:10.1016/j.seares.2011.07.009

Bernard, I., Massabuau, J.C., Ciret, P., Sow, M., Sottolichio, A., Pouvreau, S. \& Tran, D. (2016) In situ spawning in a marine broadcast spawner, the Pacific oyster Crassostrea gigas: Timing and environmental triggers. Limnology and Oceanography, 61(2), 635-645. doi: 10.1002/lno.10240

Beukema, J., Dekker, R. \& Jansen, J. (2009) Some like it cold: populations of the tellinid bivalve Macoma balthica (L.) suffer in various ways from a warming climate. Marine Ecology Progress Series, 384, 135-145. doi:10.3354/meps07952

Cardoso, J.F.M.F., Langlet, D., Loff, J.F., Martins, A.R., Ij, J., Santos, P.T. \& Van Der Veer, H.W. (2007) Spatial variability in growth and reproduction of the Pacific oyster Crassostrea gigas ( Thunberg , 1793 ) along the west European coast. Journal of Sea Research, 57, 303-315. doi:10.1016/j.seares.2006.11.003

Cardoso, J.F.M.F, Nieuwland, G., Witbaard, R., van der Veer, H.W. \& Machado, J.P. (2013) Growth increment periodicity in the shell of the razor clam Ensis directus using stable isotopes as a method to validate age. Biogeosciences. 10, 4741-4750. doi:10.5194/bg-10-4741-2013

Castaños, C., Pascual, M. \& Camacho, A. P. (2009) Reproductive biology of the nonnative oyster, 
Crassostrea gigas (Thunberg, 1793), as a key factor for its successful spread along the rocky shores of northern Patagonia, Argentina. Journal of Shellfish Research, 28(4), 837-847.

Chávez-Villalba, J., Pommier, J., Andriamiseza, J., Pouvreau, S., Barret, J., Cochard, J. C. \& Le Pennec, M. (2002) Broodstock conditioning of the oyster Crassostrea gigas: origin and temperature effect. Aquaculture, 214(1), 115-130.

Cloern, J. E. (2001) Our evolving conceptual model of the coastal eutrophication problem. Marine Ecology Progress Series, vol. 210:223-253.

Deslous-Paoli, J. M. (1982) Croissance et qualité de l'huître Crassostrea gigas Thunberg en élevage dans le bassin de Marennes-Oléron. TETHYS, 10(4), 365-371.

Dutertre, M., Beninger, P. G., Barillé, L., Papin, M. \& Haure, J. (2010) Rising water temperatures, reproduction and recruitment of an invasive oyster, Crassostrea gigas, on the French Atlantic coast. Marine Environmental Research, 69(1), 1-9.

Dutertre, M., Ernande, B., Haure, J. \& Barillé, L. (2016) Spatial and temporal adjustments in gill and palp size in the oyster Crassostrea gigas. Journal of Molluscan Studies, 1-8. doi:10.1093/mollus/eyw025

Edwards, M. \& Richardson, A. J. (2004) Impact of climate change on marine pelagic phenology and trophic mismatch. Nature, 430, 881-884.

Enriquez-Diaz, M., Pouvreau, S., Chavez-Villalba, J. \& Le Pennec, M. (2009) Gametogenesis, reproductive invest- ment, and spawning behavior of the Pacific giant oyster Crassostrea gigas: evidence of an environment-dependent strategy. Aquaculture International, 17,491-506.

Filgueira, R., Rosland, R. \& Grant, J. (2011). A comparison of scope for growth (SFG) and dynamic energy budget (DEB) models applied to the blue mussel (Mytilus edulis). Journal of Sea Research, 66, 403-410. doi:10.1016/j.seares.2011.04.006

Filgueira, R., Guyondet, T., Comeau, L.A. \& Grant, J. (2014) A fully-spatial ecosystem-DEB model of oyster (Crassostrea virginica) carrying capacity in the Richibucto Estuary, Eastern Canada. 
Journal of Marine System, 136, 42-54. doi:10.1016/j.jmarsys.2014.03.015

Gangnery A, Bacher C, Buestel D (2004) Application of a population dynamics model to the Mediterranean mussel, Mytilus galloprovincialis, reared in Thau Lagoon (France). Aquaculture 229:289-313.

Gosling, E.M. (2003) Bivalve molluscs: biology, ecology and culture. Blackwell Publishing, Oxford, U.K, 456 p.

Hoegh Guldberg, O. and Bruno, J. F. (2010). The Impact of Climate Change on the World's Marine Ecosystems. Science, Vol. 328, Issue 5985, 1523-1528. doi: 10.1126/science.1189930

Kang, Ch-K., Park, M.S., Lee, P. Y., Choi, W-J.\& Lee, W-Ch. (2000) Seasonal variations in condition, reproductive activity, and biochemical composition of the Pacific oyster, Crassostrea gigas (Thunberg), in suspended culture in two coastal bays of Korea. Journalof Shellfish Research. 19(2),771-778.

Kang, S.G., Choi, K.S., Bulgakov, A.A., Kim, Y. \& Kim, S.Y. (2003) Enzyme-linked immunosorbent assay (ELISA) used in quantification of reproductive output in the Pacific oyster, Crassostrea gigas, in Korea. Journal of Experimental Marine Biology and Ecology. 282, 1-21.

Kimmel, D.G. \& Newell, R.I.E. (2007) The influence of climate variation on eastern oyster (Crassostrea virginica) juvenile abundance in Chesapeake Bay. Limnology and Oceanography, $52,959-965$.

Kooijman, S.A.L.M. (2010) Dynamic energy budget theory for metabolic organisation. Cambridge university press, $514 \mathrm{p}$.

Kromkamp, J.C. \& Van Engeland, T. (2009) Changes in phytoplankton biomass in the western Scheldt estuary during the period 1978-2006, in: ASLO Aquatic Sciences Meeting 2009: A Cruise Through Nice Waters, 25-30 January 2009, Nice, France,141 p.

Lavaud, R., Flye-Sainte-Marie, J., Jean, F., Emmery, A., Strand, Ø. \& Kooijman, S.A.L.M. (2014) Feeding and energetics of the great scallop, Pecten maximus, through a DEB model. Journal of 
Sea Research. 94, 5-18. doi:10.1016/j.seares.2013.10.011

Lejart, M. (2009) Etude du processus invasif de Crassostrea gigas en Bretagne: Etat des lieux, dynamique et conséquences écologiques (Doctoral dissertation, Université de Bretagne occidentale-Brest, 256 p).

Lévy, M., Jahn, O., Dutkiewicz, S., Follows, M.J. \& d'Ovidio, F. (2015). The dynamical landscape of marine phytoplankton diversity. J.R.Soc. Interface 12: 20150481. doi:10.1098/rsif.2015.0481L'Hévéder, B., Speich, S., Ragueneau, O., Gohin, F. \& Bryère, P. (2017) Observed and projected sea surface temperature seasonal changes in the Western English Channel from satellite data and CMIP5 multi-model ensemble. International Journal of Climatology, 37, 2831-2849. doi:10.1002/joc.4882

Liepert B.G. (2002). Observed reductions of surface solar radiation at sites in the United States and worldwide from 1961 to 1990. Geophysical Research Letters, Vol. 29, №10, 1421. doi:10.1029/2002GL014910

Mann, R. (1979) Some biochemical and physiological aspects of growth and gametogenesis in Crassostrea gigas and Ostrea edulis grown at sustained elevated temperatures. Journal of the Marine Biological Association of the United Kingdom, 59, 95-110.

Martin, J. \& Planque, B. (2006) Variability in the onset of hatching of Maja brachydactyla Balss, 1922 (Brachyura: Majidae) in the English Channel in relation to sea temperature. Invertebrate Reproduction \& Development, 49(3), 143-150. doi: 10.1080/07924259.2006.9652205

Menge, B.A., Chan, F., Nielsen, K.J., Lorenzo, E.D. \& Lubchenco, J. (2009) Climatic variation alters supply-side ecology: impact of climate patterns on phytoplankton and mussel recruitment. Ecological Monographs, 79, 379-395. doi:10.1890/08-2086.1

Miossec, L., Le Deuff, R. M. \& Goulletquer, P. (2009) Alien species alert: Crassostrea gigas (Pacific oyster). ICES Cooperative Research Report No. 299, 42 p.

Morgan, E., O' Riordan, R.M. \& Culloty, S.C. (2013) Climate change impacts on potential 
recruitment in an ecosystem engineer. Ecology and Evolution, 3, 581-94. doi:10.1002/ece3.419

Montalto, V., Rinaldi, A. \& Sarà, G. (2015). Life history traits to predict biogeographic species distributions in bivalves. The science of Nature , 102: 61. doi: 10.1007/s00114-015-1313-4

Morán, X. A. G., López-Urrutia, A., Calvo-Díaz, L., Li, W. K. W. (2010). Increasing importance of small phytoplankton in a warmer ocean. Glob. Change Biol. 16, 1137-1144. doi:10.1111/j.13652486.2009.01960.x

Mori, K. (1979) Effects of artificial eutrophication on the metabolism of the Japanese oyster Crassostrea gigas. Marine Biology, 53, 361-369.

Moss, R.H., Edmonds, J.A., Hibbard, K.A., Manning, M.R., Rose, S.K., Vuuren, D.P. Van, Carter, T.R., Emori, S., Kainuma, M., Kram, T., Meehl, G.A., Mitchell, J.F.B., Nakicenovic, N., Riahi, K., Smith, S.J., Stouffer, R.J., Thomson, A.M., Weyant, J.P. \& Wilbanks, T.J. (2010) The next generation of scenarios for climate change research and assessment. Nature, 463, 747-756. doi:10.1038/nature08823

Navarro, J.M. \& Thompson, R.J. (1996) Physiological energetics of the horse mussel Modiolus modiolus in a cold ocean envrionment. Marine Ecology Progress Series, 138, 135-148.

Niu, L., Van Gelder, P.H.A.J.M., Guan, Y. \& Vrijling, J.K. (2015). Uncertainty Analysis and Modelling of Phytoplankton Dynamics in Coastal Waters. Journal of Environment Protection and Sustainable Development, Vol. 1, No. 4, 193-202.

Olive, P.J.W. (1992). The adaptive significance of seasonal reproduction in marine invertebrates: the importance of distinguishing between models. Invertebr Reprod Dev, 22: 165-174.

Olive, P.J.W. (1995). Annual breeding cycles in marine invertebrates and environmental temperature:probing the proximate and ultimate causes of reproductive synchrony. J Therm Biol 20: 79-90.

Parmesan, C., \& Yohe, G. (2003) A globally coherent fingerprint of climate change impacts across natural systems. Nature, 421, 37-42. 
Parmesan, C. (2007) Influences of species, latitudes and methodologies on estimates of phenological response to global warming. Global Change Biology, 13(9), 1860-1872.

Petton, S., Le Roy, V., Bellec, G., Queau, I., Le Souchu, P. \& Pouvreau, S. (2016) Marine environmental station database of Daoulas bay. SEANOE. doi: 10.17882/42493

Philippart, C.J.M., van Aken, H.M., Beukema, J.J., Bos, O.G., Cadee, G.C. \& Dekker, R. (2003) Climate-related changes in recruitment of the bivalve Macoma balthica. Limnology and Oceanography, 48 (6), 2171-2185.

Picoche, C., Le Gendre, R., Flye-Sainte-Marie, J., Françoise, S., Maheux, F., Simon, B. \& Gangnery, A. (2014) Towards the Determination of Mytilus edulis Food Preferences Using the Dynamic Energy Budget (DEB) Theory. PLoS ONE, 9, e109796.

Pouvreau, S., Bourles, Y., Lefebvre, S., Gangnery, A. \& Alunno-Bruscia, M. (2006) Application of a dynamic energy budget model to the Pacific oyster, Crassostrea gigas, reared under various environmental conditions. Journal of Sea Research, 56, 156-167.

Pouvreau, S., Maurer, D., Auby, I., Lagarde, F., Le Gall, P., Cochet, H., Bouquet, A.L., Geay, A. \& Mille, D. (2016) VELYGER Database: The Oyster Larvae Monitoring French Project. SEANOE. doi:10.17882/41888

R Core Team (2018). R: A language and environment for statistical computing. R Foundation for Statistical Computing, Vienna, Austria. URL http://www.R-project.org/.

Reitzel, A.M., Miner, B.G. \& McEdward, L.R. (2004). Relationships between spawning date and larval development time for benthic marine invertebrates: a modeling approach. Mar Ecol Prog Ser, 280: 13-23.

Robert, R., Rico-Villa, B. \& Mingant, C. (2006) Influence of sole and plurispecific diets on larval consumption and development of Pacific oyster Crassostrea gigas (Thunberg). Oyster Research Institue News, 18, 19-24.

Roderick, M.L. \& Farquhar, G.D. (2002). The cause of decreased pan evaporation over the past 50 
years. Science, 298(5597),1410-1. doi: 10.1126/science.1075390

Rosland, R., Strand, Ø., Alunno-Bruscia, M., Bacher, C., Strohmeier, T. (2009) Applying dynamic energy budget (DEB) theory to simulate growth and bio-energetics of blue mussels under low seston conditions. Journal of Sea Research, 62, 49-61.

Sastry, A.N. (1979) Pelecypoda (excluding Ostreidae), 113-292, in: Giese, A.C. \& Blake, N. J. [eds.], Reproduction in marine vertebrates, Vol. 5., Academic.

Seaman, M. N. L. (1991) Survival and aspects of metabolism in oysters, Crassostrea gigas, during and after prolonged air storage. Aquaculture, Vol. 93, issue 4, 389-395. doi: 10.1016/00448486(91)90228-Y

Shephard, S., Beukers-Stewart, B., Hiddink, J.G., Brand, A.R. \& Kaiser, M.J. (2009) Strengthening recruitment of exploited scallops Pecten maximus with ocean warming. Marine Biology, 157, 91-97. doi:10.1007/s00227-009-1298-7

Sommer, U., Gliwicz, Z. M., Lampert W. \& Duncan, A. (1986). The PEG-model of seasonal succession of planktonic events in fresh waters. Archiv fur Hydrobiologie 106:433-471.

Sommer, U., Adrian, R., De Senerpont Domis, L., Elser, J.J., Gaedke, U, Ibelings, B., Jeppesen, E., Lürling, M., Molinero, J.C., Mooij, W.M., van Donk, E. \& Winder, M.(2012). Beyond the plankton ecology group (PEG) model: mechanisms driving plankton succession. Annual Review of Ecology, Evolution and Systematics, Vol. 43:429-448. doi:10.1146/annurev-ecolsys-110411160251

Soniat, T.M.; Klinck, J.M.; Powell, E.N \& Hofmann, E.E (2006) Understanding the Success and Failure of Oyster Populations: Climatic Cycles and Perkinsus Marinus. Journal of Shellfish Research, 25(1), 83-93: doi:10.2983/0730-8000(2006)25[83:utsafo]2.0.co;2.

Stanhill, G. \& Cohen, S. (2001). Global Dimming: A Review of the Evidence for a Widespread and Significant Reduction in Global Radiation with Discussion of Its Probable Causes and Possible Agricultural Consequences. Agricultural and Forest Meteorology, 107, 255-278. 
doi:10.1016/S0168-1923(00)00241-0

Starr, M., Himmelman, J. \& Therriault, J. (1990) Direct coupling of marine invertebrate spawning with phytoplankton blooms. Science, 247(4946):1071.

Steele, S., \& Mulcahy, M. (1999) Gametogenesis of teh Oyster Crassostrea gigas in southern Ireland. J. Mar. Biol. Ass. UK., 79, 673-686. http://doi.org/10.1017/S0025315498000836

Taylor, K.E. (2001) Summarizing multiple aspects of model performance in a single diagram. Journal of Geophysical Research: Atmospheres, 106, 7183-7192.

Thomas, Y., Mazurié, J., Alunno-Bruscia, M., Bacher, C., Bouget, J.-F., Gohin, F., Pouvreau, S. \& Struski, C. (2011) Modelling spatio-temporal variability of Mytilus edulis (L.) growth by forcing a dynamic energy budget model with satellite-derived environmental data. Journal of Sea Research, 66 (4), 308-317.

Thomas, Y., Pouvreau, S., Alunno-Bruscia, M., Barillé, L., Gohin, F., Bryère, P. \& Gernez, P. (2016) Global change and climate-driven invasion of the Pacific oyster (Crassostrea gigas) along European coasts: A bioenergetics modelling approach. Journal of Biogeography, 43, 568-579. doi:10.1111/jbi.12665

Valdizan, A., Beninger, P. G., Decottignies, P., Chantrel, M. \& Cognie, B. (2011) Evidence that rising coastal seawater temperatures increase reproductive output of the invasive gastropod Crepidula fornicata. Marine Ecology Progress Series, 438, 153-165.

Walther, G. R., Post, E., Convey, P., Menzel, A., Parmesan, C., Beebee, T.J.C., Fromentin, J.M., Hoegh-Guldberg, O., \& Bairlein, F. (2002) Ecological responses to recent climate change. Nature, 416, 389-395.

Winder, M., Berger, S. A., Lewandowska, A., Aberle, N., Lengfellner, K, Sommer, U \& Diehl, S (2012). Spring phenological responses of marine and freshwater plankton to changing temperature and light conditions. Marine Biology. doi:10.1007/s00227-012-1964-z 
Appendix A: Supplementary details on the oyster-DEB model design, and additional figure (Fig. A) and tables (Tables A.1 and A.2).

The DEB model is a mechanistic model that describes the dynamics of three state variables: $\mathrm{E}$, the energy stored in reserves, $\mathrm{V}$, the volume of structure, and $E_{R}$, the energy allocated to reproduction. To improve the accuracy of the DEB model for reproductive output, Bernard et al. (2011) refined the processes of energy allocation to gametogenesis and resorption. A fourth state variable was then added: EGO, the energy store in gametes. Briefly, the model dynamics can be explained as follows: the reserve mobilization rate $\dot{p}_{C 1}$ is divided in two parts. A first constant fraction, $\mathbf{\kappa}$, is allocated to structural growth and maintenance, and the remainder, $1-\mathbf{\kappa}$, is allocated to development/reproduction and maturity maintenance. In the same way, gonad construction is modeled through the gamete mobilization rate, $\dot{p}_{C 2}$. In case of starvation, priority is given to the maintenance costs: $\dot{p}_{M 1}$ for maturity maintenance and $\dot{p}_{J}$ for somatic maintenance. Thus, gametogenesis flux is allocated to somatic and maturity maintenance through the secondary maintenance, $\dot{p}_{M 2}$. If $\dot{p}_{M 2}$ is not enough to cover all maintenance costs, the gamete resorption rate, $\dot{p}_{L 2}$ takes over. In case of extreme starvation, the structure is broken down at the rate $\dot{p}_{L 1}$.

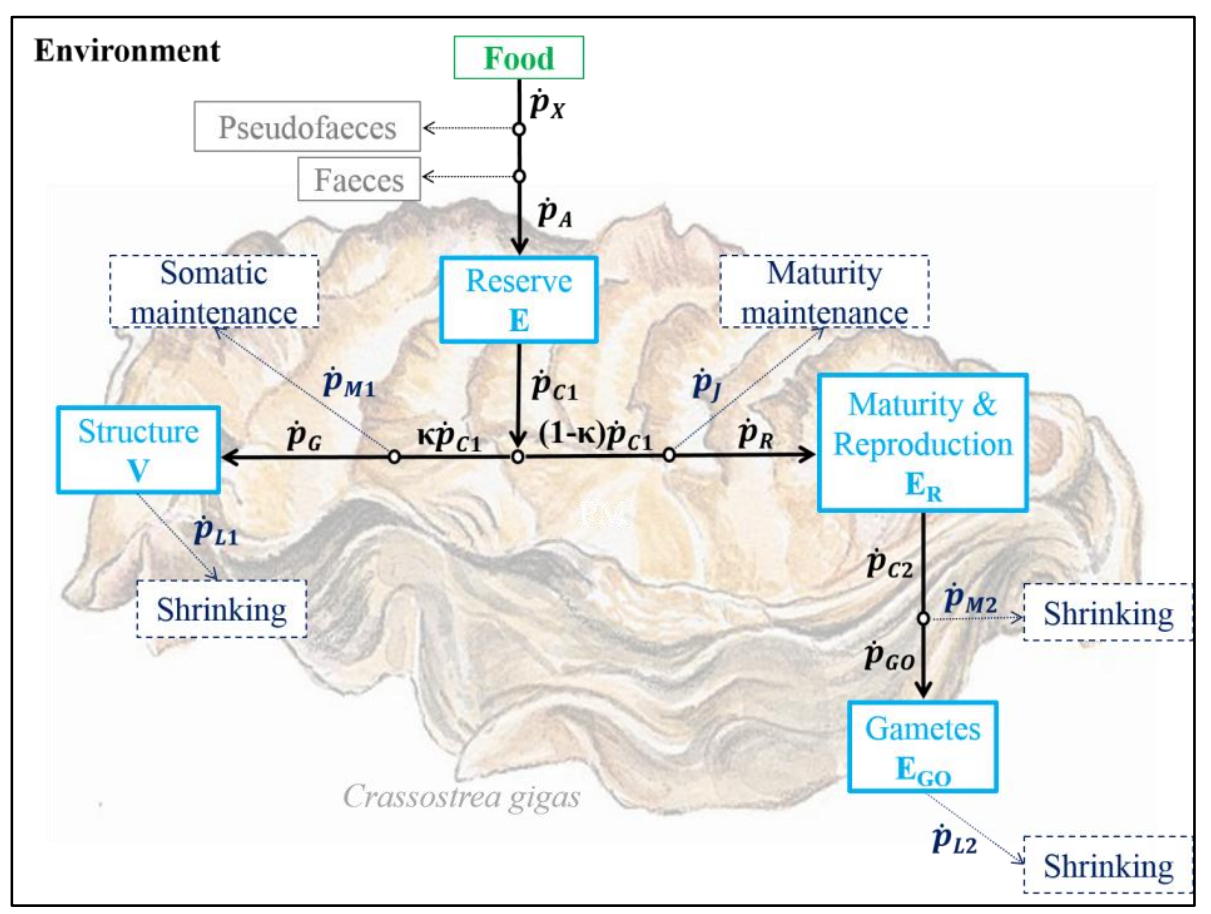


Fig. A: Schema of the C. gigas DEB model with 4 state variables adapted from Bernard et al. 2011.

Sources of energy to support somatic maintenance during prolonged starvation conditions are indicated in blue.

Table A.1: Equations of the C. gigas DEB model (Thomas et al., 2016)

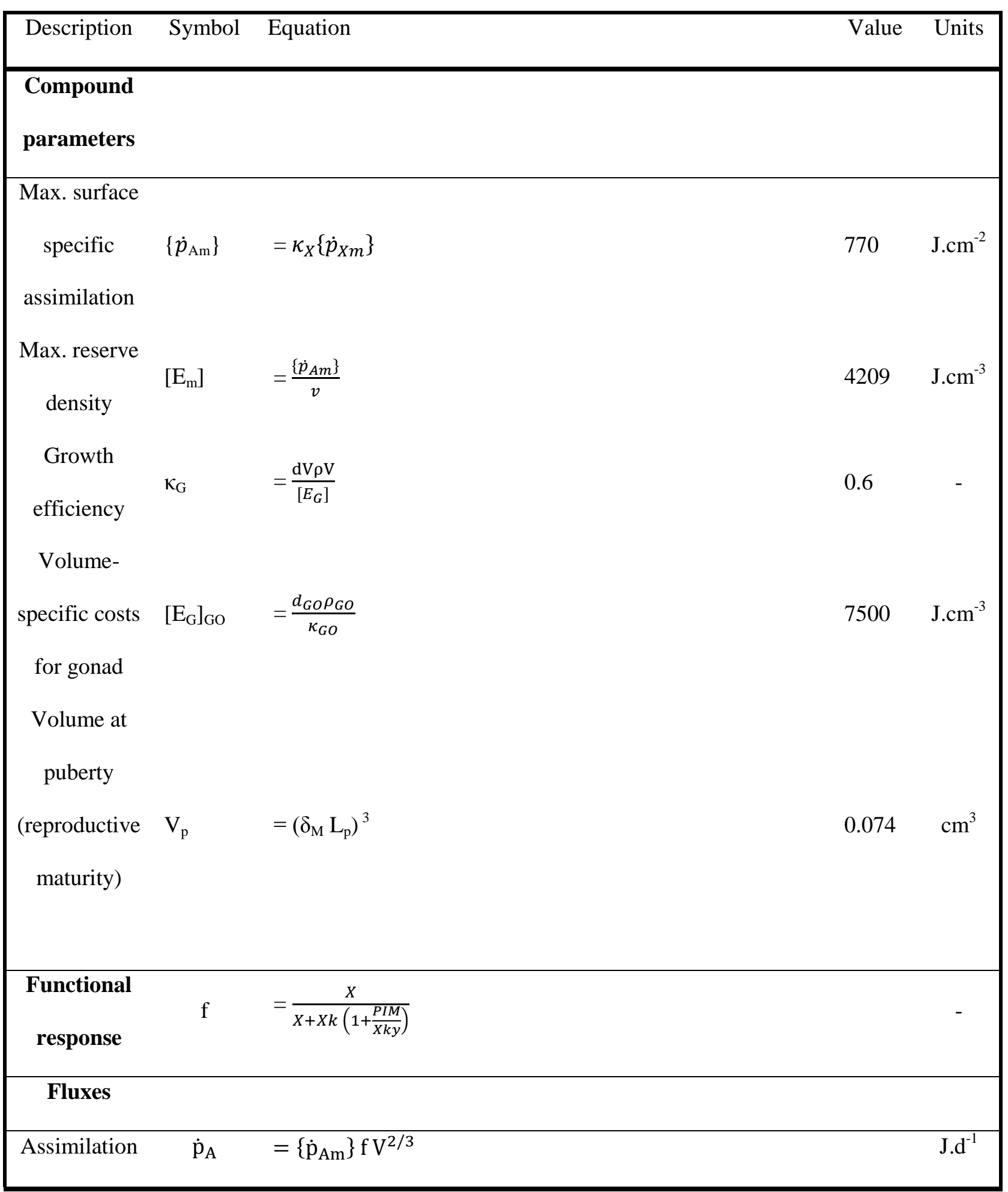




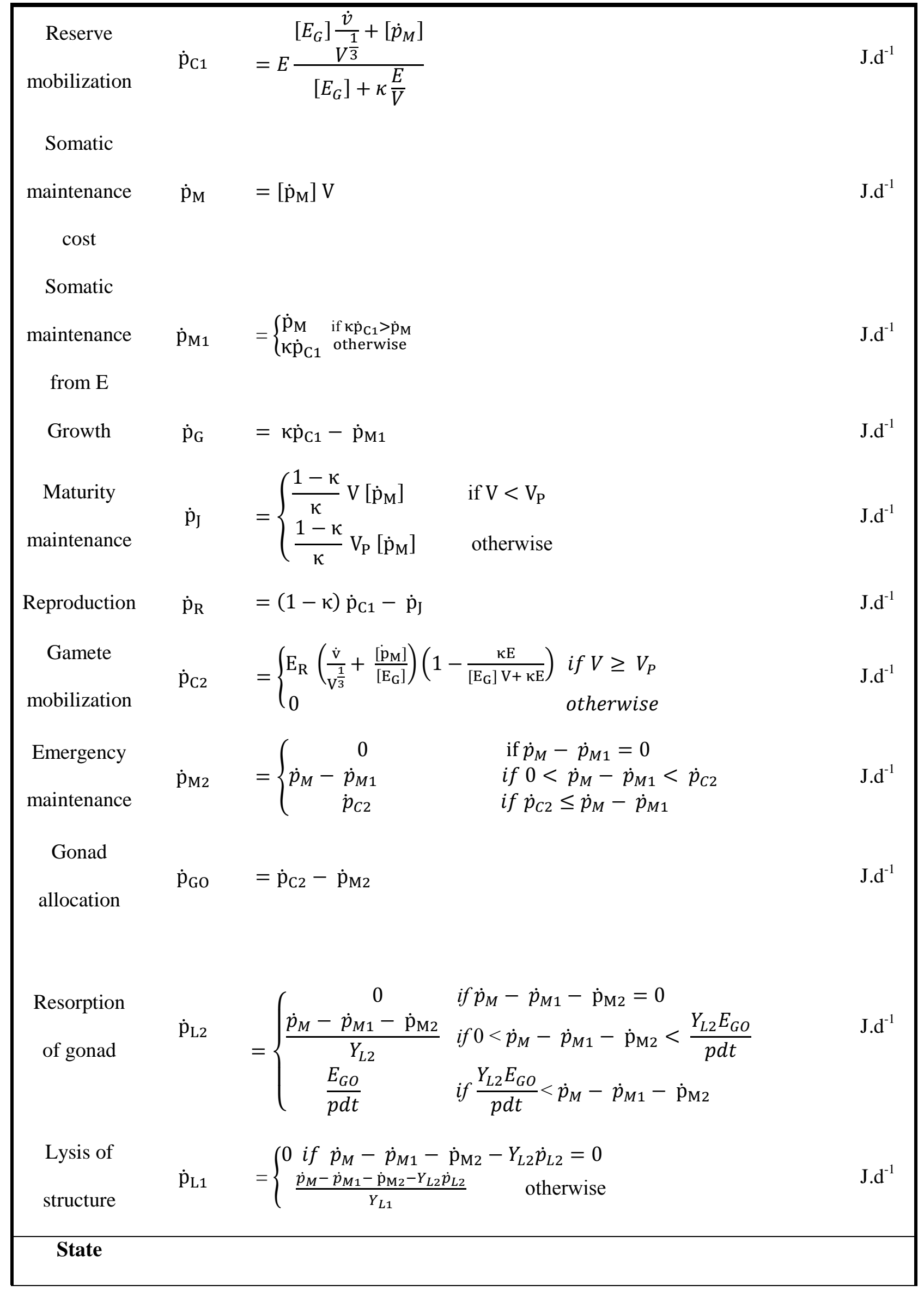




\begin{tabular}{|c|c|c|c|c|}
\hline \multicolumn{5}{|l|}{ variables } \\
\hline Reserve & $\frac{d E}{d t}$ & $=\dot{\mathrm{p}}_{\mathrm{A}}-\dot{\mathrm{p}}_{\mathrm{C} 1}$ & & $\mathrm{~J}$ \\
\hline Structure & $\frac{d V}{d t}$ & $=\frac{\kappa_{G} \dot{p}_{G}-\dot{p}_{L 1}}{\rho_{V} d_{V}}$ & & $\mathrm{~cm}^{3}$ \\
\hline Reproduction & $\frac{d E_{R}}{d t}$ & $=\left\{\begin{array}{l}\dot{p}_{R}-\dot{p}_{C 2} \\
0\end{array}\right.$ & $\begin{array}{l}\text { if } V \geq V_{P} \\
\text { otherwise }\end{array}$ & $\mathrm{J}$ \\
\hline Gametes & $\frac{d E_{G O}}{d t}$ & $=\kappa_{G O} \dot{\mathrm{p}}_{\mathrm{GO}}-\dot{\mathrm{p}}_{\mathrm{L} 2}$ & & $\mathrm{~J}$ \\
\hline
\end{tabular}

Table A.2: Initial values of the state variables of the $C$. gigas DEB model. Values vary among individuals according to their initial length $\left(\mathrm{L}_{0}\right)$ and initial dry flesh mass $\left(\mathrm{W}_{\mathrm{d} 0}\right)$.

\begin{tabular}{|lcrcr|}
\hline \multicolumn{1}{|c}{ Initial conditions } & Symbol & Equation & Value & Units \\
\hline Initial structure & $V_{0}$ & $=\left(\delta_{\mathrm{M}} \mathrm{L}_{0}\right)^{3}$ & & $\mathrm{~cm}^{3}$ \\
Initial reserve & $E_{0} \quad=f\left[E_{m}\right] V_{0}$ & & $\mathrm{~J}$ \\
Initial gametes & $E_{G O 0}$ & & 0 & $\mathrm{~J}$ \\
Initial reproduction & $E_{R 0}$ & $=\rho_{E}\left(W_{d 0}-V_{0} d_{V}\right)-E_{0}-E_{G O 0}$ & & $\mathrm{~J}$ \\
\hline
\end{tabular}

Table A.3: List of the parameters used in the DEB model of $C$. gigas. All rate parameters are provided at $\mathrm{T}_{1}=20^{\circ} \mathrm{C}(=293.15 \mathrm{~K})$

\begin{tabular}{|c|c|c|c|}
\hline Description & Symbol & Value & Units \\
\hline \multicolumn{4}{|l|}{ Biological parameters } \\
\hline Shape coefficient & $\delta_{\mathrm{M}}$ & 0.175 & - \\
\hline Length at puberty (reproductive maturity) & $\mathrm{L}_{\mathrm{p}}$ & 2.400 & $\mathrm{~cm}$ \\
\hline \multicolumn{4}{|l|}{ Reserve parameters } \\
\hline Maximum surface-specific ingestion rate & $\left\{\dot{p}_{\mathrm{Xm}}\right\}$ & 1025 & $\mathrm{~J} \cdot \mathrm{cm}^{-2} \cdot \mathrm{d}^{-1}$ \\
\hline
\end{tabular}


Volume-specific maintenance costs
Energy conductance
Assimilation efficiency
Energy content of $1 \mathrm{~g}$ (dry weight) of reserve

$$
\begin{gathered}
{\left[\dot{p}_{\mathrm{M}}\right]} \\
\dot{v} \\
\kappa_{\mathrm{X}}
\end{gathered}
$$

0.183

$\mathrm{cm} \cdot \mathrm{d}^{-1}$

$[0 ; 0.80]$

$\rho_{\mathrm{E}}$

19600

$$
\text { J.g }{ }^{-1}
$$

\section{Structure parameters}

Volume specific cost for growth

$\left[\mathrm{E}_{\mathrm{G}}\right]$

3900

$\mathrm{J} . \mathrm{cm}^{-3}$

Allocation fraction to growth and maintenance

$\kappa$

0.45

Density of structure

$d_{V}$

0.15

g.cm ${ }^{-3}$

Energy content of $1 \mathrm{~g}$ (dry weight) of structure

$\rho_{\mathrm{V}}$

15600

J.g $\mathrm{g}^{-1}$

Yield of structural tissue used for maintenance

$\mathrm{Y}_{\mathrm{L} 1}$

\section{Reproduction parameters}

Reproduction efficiency

$\kappa_{\mathrm{Go}}$

0.90

Density of gonad

$\mathrm{d}_{\mathrm{GO}}$

0.31

g.cm ${ }^{-3}$

Yield of gonad tissue used for maintenance

$\mathrm{Y}_{\mathrm{L} 2}$

0.25

Energy content of $1 \mathrm{~g}$ of gonad

$\rho_{\mathrm{GO}}$

21630

J.g-1

Temperature threshold for spawning

$\mathrm{T}_{\mathrm{S}}$

18.70

${ }^{\circ} \mathrm{C}$

Gonado-somatic index threshold for spawning

$\mathrm{G}_{\mathrm{SI}}$

0.472

\section{Environmental parameters (Bay of Brest)}

Food half saturation coefficient

PIM half saturation coefficient

Percentage of immersion (mean)
$\mathrm{X}_{\mathrm{k}}$

$\mathrm{X}_{\mathrm{ky}}$

$t_{\text {im }}$

0.836
cell/L

$\mathrm{mg} / \mathrm{L}$

$\mathrm{T}_{\mathrm{A}}$ 5800 
Lower boundary tolerance range

$\begin{array}{lll}\mathrm{T}_{\mathrm{L}} & 281.15 & \mathrm{~K} \\ \mathrm{~T}_{\mathrm{H}} & 300.15 & \mathrm{~K} \\ & & \end{array}$

Arrhenius temperature for lower boundary

$\mathrm{T}_{\mathrm{AL}}$

75000

K

Arrhenius temperature for upper boundary

$\mathrm{T}_{\mathrm{AH}}$

30000

K 
Appendix B: Supplementary details on the interpolation of seawater temperature data, and additional figures (Fig. B.1 and B.2).

A dataset of air and seawater temperatures from 2006 to 2014 were analyzed for the station Pointe du Chateau in the Bay of Brest (Brittany, France) (Fig. B.1). Seawater temperature data were acquired with probes fixed on a metallic structure positioned at $50 \mathrm{~cm}$ above the sediment bottom on the foreshore in the intertidal zone. Since 2006, several types of probes have been used, which are listed with the data: EBI 85 from Global Water (http://www.globalw.com), DS5 Hydrolab from OTT (http://www.ott.com), and SP2T, STPS or SMATCH from NKE (http://www.nke-instrumentation.fr). For each of these probes, temperature and salinity accuracies are also available. Time frequency of recording can differ from one probe to another but tends to be 15 minutes (Petton et al., 2016). Air temperature data were recorded daily by METEO FRANCE at the Lanvéoc site.

Air temperature shows more extreme values compared with seawater temperature. Therefore, a moving average of five days was used to smooth air temperature data. Then, the relation between air and seawater temperature was examined, revealing an S-shaped relationship. A logistic type function was then used. This technique was developed by Mohseni et al. (1998) in order to examine air and water temperature relationships on a daily or weekly basis. It is a three parameter model defined using the following equation:

$$
\mathrm{SST}=\operatorname{Asym} /\left(1+\mathrm{e}^{\frac{x m i d-\mathrm{AT}}{\text { scal }}}\right)
$$

Where Asym $\left({ }^{\circ} \mathrm{C}\right)$ is a coefficient that estimates maximum seawater temperature and represents the asymptote and $x \operatorname{mid}\left({ }^{\circ} \mathrm{C}\right)$ is a coefficient that represents the $\mathrm{x}$ value at the inflection point of the curve. The value of SSlogis will be Asym/2 at $x \operatorname{mid} . \operatorname{Scal}\left({ }^{\circ} \mathrm{C}\right)$ is the scale parameter on the input (values at which to evaluate the model) axis. SST is the seawater surface temperature and ATis the air temperature. 

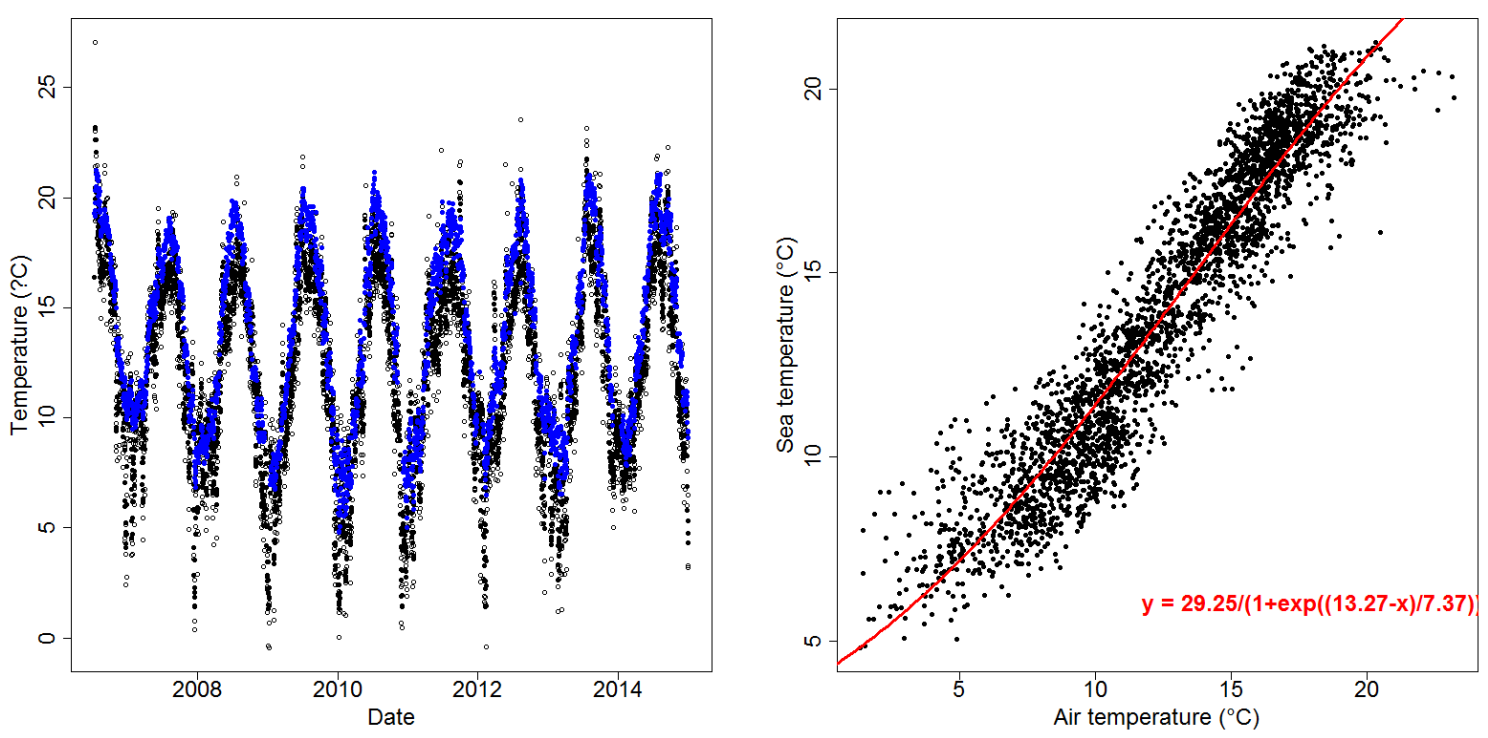

Fig. B.1: Relation between daily air temperature and daily seawater temperature in the Bay of Brest (from 2006 to 2014): (a) daily air temperature (empty circles), smoothed air temperature (black circles) and seawater temperature (blue circles); (b) smoothed air temperature and a fitted logistic function.

Using this logistic regression we reconstructed seawater temperature from 1960 based on air temperature for the retrospective study.

For the projection studies, the seawater temperature used was the same as that in the reconstructive study. Monthly air temperatures were available from CERFACS for the period 2006 to 2100. In order to avoid step transformation, the temporal scale of air temperature was kept. Then, contrary to the historical data, which are daily, projection data were monthly and smoother. Instead of a logistic regression method, a linear regression method was used between monthly air temperature and monthly seawater temperature from 2006 to 2014, according to the following equation:

$$
\mathrm{SST}=a \times \mathrm{AT}+b
$$

Where $a$ is a coefficient that estimates the determination coefficient, $b$ is a coefficient that represents the intercept, SST is the seawater surface temperature, and AT is the air temperature.

Each projection (RCP2.6 and RCP8.5) had their own temperature variation, and then a linear regression was made for each case. 


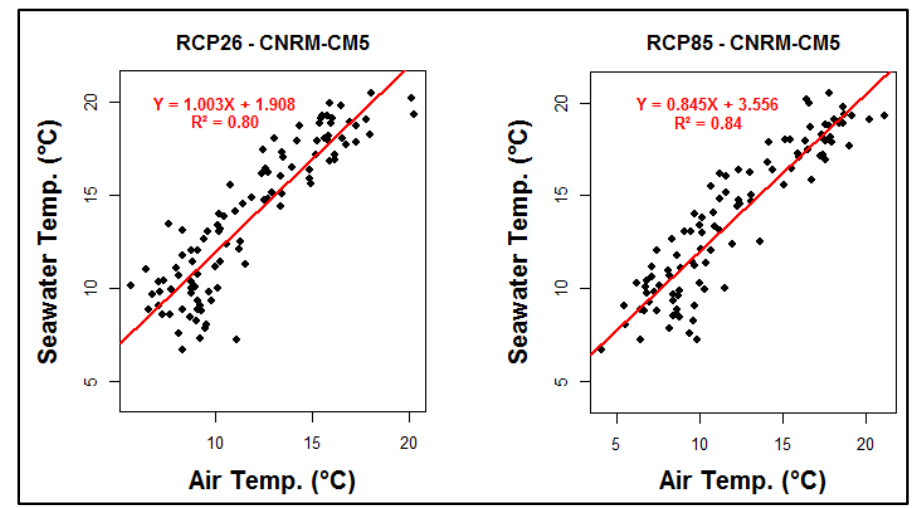

Fig B.2: Relation between monthly air temperature (from the RCP scenarios) and monthly seawater temperature in the Bay of Brest (from 2006 to 2014): on the left, monthly air temperatures on monthly seawater temperature under the RCP2.6 scenario with the CNRM-CM5 model; on the right, monthly air temperatures on monthly seawater temperature under the RCP8.5 scenario with the CNRM-CM5 model.

From this linear regression we projected SST from 2040 to 2100 based on air temperature. 
Appendix C: Supplementary details on climatic projection models and additional figures (Fig. C.1 and C.2) and tables (Table C.1 and C.2).

Representative Concentration Pathways (RCP) are the latest generation of scenarios that provide inputs to climate models. The purpose of using scenarios is not to predict the future, but to explore both the scientific and real-world implications of different plausible futures (van Vuuren et al., 2011).

The IPCC authors chose four emission trajectories to focus on and labeled them based on how much heating they would produce at the end of the century: $8.5,6,4.5$, and 2.6 watts per square meter $\left(\mathrm{W} . \mathrm{m}^{-2}\right.$ ). Figure C.1 shows the annual carbon dioxide emissions (in billions of tons of carbon) until 2100 for each of the RCPs.

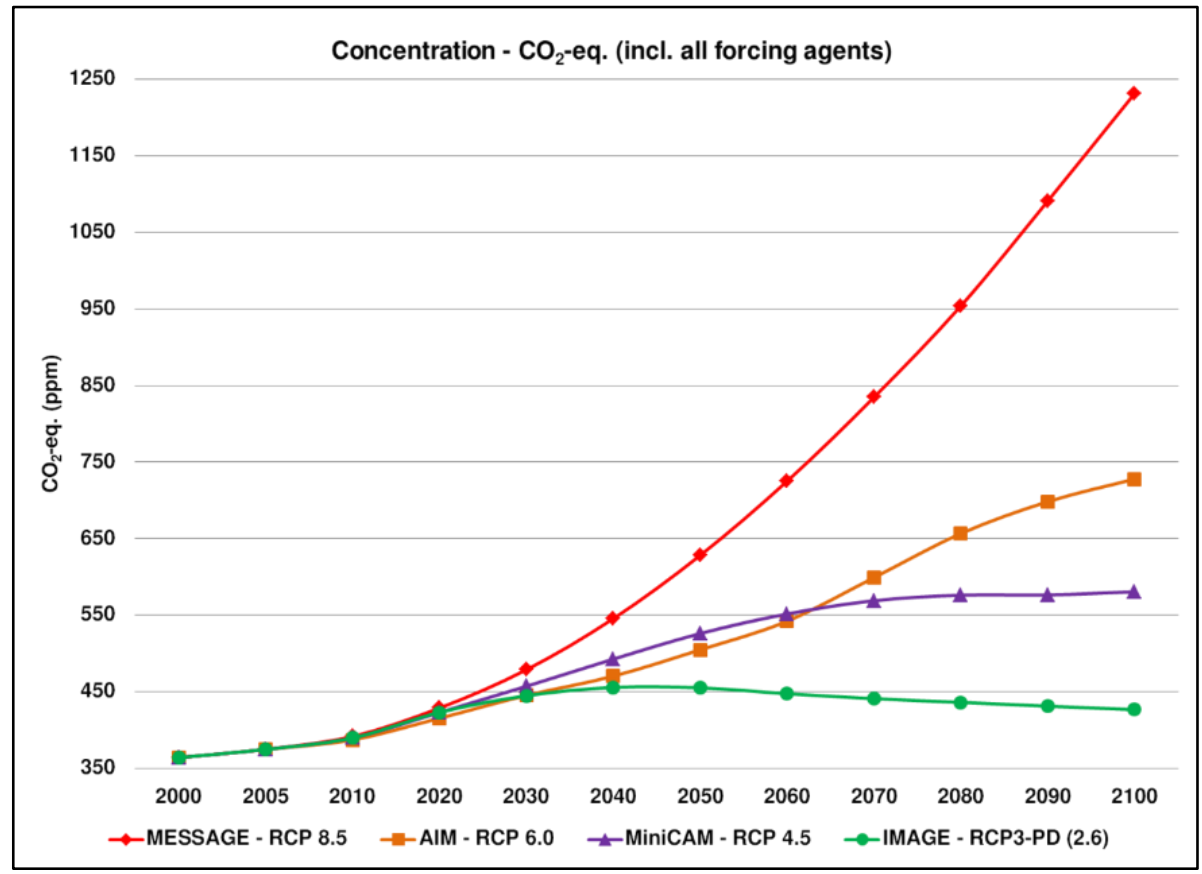

Fig. C.1: Emissions of annual $\mathrm{CO}_{2}$ across the RCPs. Scenario RCP2.6 (IMAGE-RCP3-PD(2.6)) is shown in green and scenario RCP8.5 (MESSAGE-RCP8.5) in red. They represent the extreme situations: RCP2.6 is the most optimistic scenario and RCP8.5 represents drastic warming. Source:

\section{IPCC Fifth Assessment Report.}

The $2.6 \mathrm{~W} \mathrm{~m}^{-2}$ scenario has greenhouse-gas emissions dropping to zero by about 2070 , and then continuing to fall, so that the world's emissions would become negative - actually withdrawing greenhouse gases from the air and locking them away — for decades. This pushes the bounds of what 
is plausible through mitigation, some experts say. At the high end, in the $8.5 \mathrm{~W} \mathrm{~m}^{-2}$ case, carbon dioxide levels would soar beyond an enormous 1,300 parts per million by the end of the century and continue to rise rapidly. 
Table C.1: Description of $\mathrm{CO}_{2}$ emission scenarios used by IPCC authors (van Vuuren et al., 2011).

\begin{tabular}{|c|c|}
\hline Projection & Description \\
\hline RCP8.5 & Rising radiative forcing pathway, leading to $8.5 \mathrm{~W} / \mathrm{m} 2$ ( 1370 ppm CO2 eq) by 2100 . \\
\hline RCP6 & $\begin{array}{l}\text { Stabilization without overshoot pathway, leading to } 6 \mathrm{~W} / \mathrm{m} 2(\sim 850 \mathrm{ppm} \mathrm{CO} 2 \mathrm{eq}) \text { at } \\
\text { stabilization after } 2100 \text {. }\end{array}$ \\
\hline $\mathrm{RCP} 4.5$ & $\begin{array}{l}\text { Stabilization without overshoot pathway, leading to } 4.5 \mathrm{~W} / \mathrm{m} 2(\sim 650 \mathrm{ppm} \mathrm{CO} 2 \mathrm{eq}) \text { at } \\
\text { stabilization after } 2100 \text {. }\end{array}$ \\
\hline RCP2.6 & $\begin{array}{l}\text { Peak in radiative forcing at } \sim 3 \mathrm{~W} / \mathrm{m} 2(\sim 490 \mathrm{ppm} \mathrm{CO} 2 \mathrm{eq}) \text { before } 2100 \text { and then decline } \\
\text { (the selected pathway declines to } 2.6 \mathrm{~W} / \mathrm{m} 2 \text { by } 2100) \text {. }\end{array}$ \\
\hline
\end{tabular}

For our study these data were obtained from the CERFACS modeling center. For each scenario (RCP2.6 and RCP8.5) 14 models were available (http://cmip-pcmdi.llnl.gov/cmip5/availability.html).

Table C.2: Description of the 14 models available for the study. The grey zones represent the two models used in the study because of their matching with the Bay of Brest environmental forcing.

\begin{tabular}{|l|l|c|l|}
\hline Modeling Center & \multicolumn{1}{|c|}{ Model } & $\mathrm{N}^{\circ}$ & \multicolumn{1}{|c|}{ Institution } \\
\hline BCC & BCC-CSM1.1 & 1 & Beijing Climate Center \\
\hline CCCma & CanESM2 & 2 & $\begin{array}{l}\text { Canadian Centre for Climate Modelling and } \\
\text { Analysis }\end{array}$ \\
\hline NCAR & CCSM4 & 3 & National Center for Atmospheric Research \\
\hline CNRM-DOE-NCAR & CESM1(CAM5) & 4 & Energy, National Center for Atmospheric Research \\
\hline CERFACS & CNRM-CM5 & & Centre Européen de Recherche et Formation \\
& & 5 & Avancées en Calcul Scientifique \\
\hline LASG-IAP & FGOALS-g2 & 6 & LASG, Institute of Atmospheric Physics \\
\hline
\end{tabular}




\begin{tabular}{|l|l|c|l|}
\hline NOAA GFDL & GFDL-CM3 & 7 & Geophysical Fluid Dynamics Laboratory \\
\hline INPE & HadGEM2-ES & 8 & Instituto Nacional de Pesquisas Espaciais \\
\hline IPSL & IPSL-CM5A-LR & 9 & Institut Pierre-Simon Laplace \\
\hline MPI-M & IPSL-CM5A-MR & 10 & \\
\hline & MPI-ESM-LR & 11 & Max Planck Institute for Meteorology \\
\hline MRI & MPI-ESM-MR & 12 & \\
\hline NCC & MRI-CGCM3 & 13 & Meteorological Research Institute \\
\hline
\end{tabular}

Among them, the CNRM-CM5 model was the most comparable to our historical temperature data in the Bay of Brest.

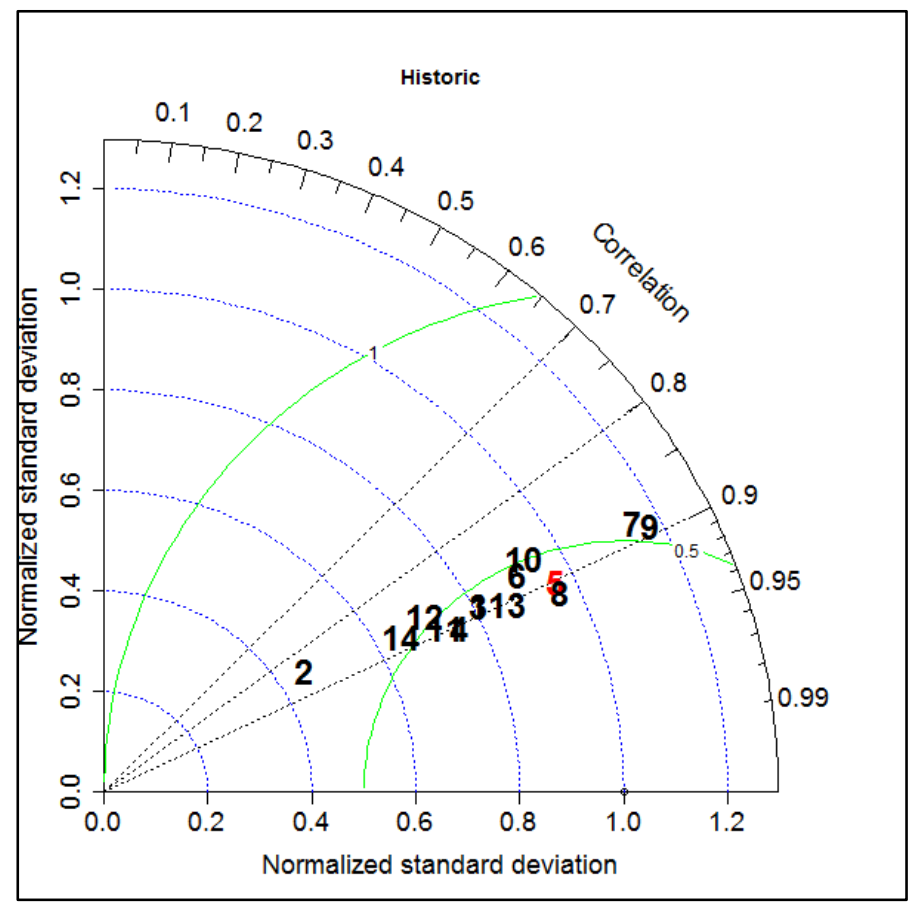

Fig. C.2: Taylor diagram giving the correlation, root-mean square difference and the ratio of variances between historical air temperature observed in the Bay of Brest since 1960 (Mod-Ref) and air temperature predicted by 14 different models (see Table C.2 above; Mod-1 to Mod-14). 
Appendix D: Supplementary table Pearson correlation (Table D).

Table D: Pearson correlation between oyster spawning date and summer sea surface temperature (1 June to 31 August). Each case was tested for the different food (A, B, C, D, E, and F) and temperature (Past, RCP2.6 and RCP8.5) scenarios.

n.s., not significant

$* P<0.05$

** $P<0.01$

*** $P<0.001$

1. Spawning date and SST Summer

$\begin{array}{lll}\text { Past } & \text { RCP2.6 } & \text { RCP8.5 }\end{array}$

\begin{tabular}{||c|ccc|ccc|ccc||}
\hline \hline & d.f. & corr & $\mathbf{P}$ value & d.f. & corr & $\mathbf{P}$ value & d.f. & corr & $\mathbf{P}$ value \\
$\mathbf{A}$ & 49 & -0.56 & $* * *$ & 55 & -0.69 & $* * *$ & 55 & -0.60 & $* * *$ \\
$\mathbf{B}$ & 39 & -0.29 & n.s. & 52 & -0.79 & $* * *$ & 52 & -0.53 & $* * *$ \\
$\mathbf{C}$ & 48 & -0.51 & $* * *$ & 55 & -0.88 & $* * *$ & 53 & -0.82 & $* * *$ \\
$\mathbf{D}$ & 35 & -0.36 & $*$ & 43 & -0.30 & $*$ & 48 & -0.57 & $* * *$ \\
$\mathbf{E}$ & 24 & -0.37 & n.s. & 39 & -0.70 & $* * *$ & 46 & -0.34 & $*$ \\
$\mathbf{F}$ & 18 & -0.43 & n.s. & 30 & -0.45 & $* *$ & 43 & -0.47 & $* *$ \\
\hline
\end{tabular}

2. Fecundity and summer SST

$\begin{array}{lll}\text { Past } & \text { RCP2.6 } & \text { RCP8.5 }\end{array}$

\begin{tabular}{||c|ccc|ccc|ccc||}
\hline \hline & d.f. & corr & $\mathbf{P}$ value & d.f. & corr & $\mathbf{P}$ value & d.f. & corr & $\mathbf{P}$ value \\
$\mathbf{A}$ & 49 & -0.15 & n.s. & 55 & 0.55 & $* * *$ & 55 & 0.53 & $* * *$ \\
$\mathbf{B}$ & 39 & 0.38 & $*$ & 52 & 0.73 & $* * *$ & 52 & 0.81 & $* * *$ \\
$\mathbf{C}$ & 48 & 0.17 & n.s. & 55 & 0.60 & $* * *$ & 53 & 0.73 & $* * *$ \\
\hline
\end{tabular}




\begin{tabular}{||c|ccc|ccc|ccc||}
$\mathbf{D}$ & 35 & 0.06 & n.s. & 43 & 0.82 & $* * *$ & 48 & 0.41 & $* *$ \\
$\mathbf{E}$ & 24 & -0.13 & n.s. & 39 & 0.00 & n.s. & 46 & 0.74 & $* * *$ \\
$\mathbf{F}$ & 18 & 0.22 & n.s. & 30 & 0.17 & n.s. & 43 & -0.01 & n.s. \\
\hline
\end{tabular}

